KOÇ UNIVERSITY-TÜSİAD ECONOMIC RESEARCH FORUM

WORKING PAPER SERIES

\title{
THE EFFECT OF HOSTING 3.4 MILLION REFUGEES ON THE HEALTH SYSTEM IN TURKEY AND INFANT, CHILD, AND ELDERLY MORTALITY AMONG NATIVES
}

\author{
Aysun Aygün \\ Murat Güray Kırdar \\ Berna Tuncay
}

Working Paper No: 2014

September 2020

This Working Paper is issued under the supervision of the ERF Directorate. Any opinions expressed here are those of the author(s) and not those of the Koç University-TÜSİAD Economic Research Forum. It is circulated for discussion and comment purposes and has not been subject to review by referees.

\section{KOÇ UNIVERSITY-TÜSİAD ECONOMIC RESEARCH FORUM \\ Rumelifeneri Yolu 34450 Sariyer/Istanbul}




\title{
The Effect of Hosting 3.4 Million Refugees on the Health System in Turkey and
}

\section{Infant, Child, and Elderly Mortality among Natives*}

\author{
Aysun Aygün ${ }^{1}$, Murat Güray Kirdar ${ }^{*}$, and Berna Tuncay ${ }^{\#}$
}

August 21, 2020

\footnotetext{
* We would like to thank Onur Altindag, Abdurrahman Aydemir, Resul Cesur, Solveig A. Cunningham, Burcay Erus, Ismet Koc, Sibel Sakarya, and the seminar participants at the Institute of Population Studies of Hacettepe University for valuable comments and suggestions. This work was supported by the Research Fund of the Istanbul Technical University (Project Number: 41602). The usual disclaimer holds.

${ }^{\dagger}$ Istanbul Technical University, Department of Economics, Istanbul 34367, Turkey. e-mail: aysunaygun@itu.edu.tr ${ }^{\text {r } B o g ̆ a z i c ̧ i ~ U n i v e r s i t y, ~ D e p a r t m e n t ~ o f ~ E c o n o m i c s, ~ B e b e k, ~ I s t a n b u l ~ 34342, ~ T u r k e y . ~ e-m a i l: ~ m u r a t . k i r d a r @ b o u n . e d u . t r ~}$ \# Koc University, Department of Economics, Rumeli Feneri Yolu, Sariyer, Istanbul 34450, Turkey. e-mail: betuncay@ku.edu.tr
} 


\begin{abstract}
As of the end of 2017, 3.4 million Syrian refugees lived in Turkey. These refugees left a country where the health system was completely broken. Several studies report that Syrian refugees faced numerous diseases during their exodus, brought certain infectious diseases to the hosting communities, and have a high incidence of health care utilization. Moreover, they have much higher fertility rates than natives (5.3 to 2.3). We examine the effect of Syrian refugees on the health infrastructure in Turkey and on natives' mortality — with a focus on infant, child, and elderly mortality. Our OLS results yield suggestive evidence of a negative effect of the refugee shock on infant and child mortality. However, we find that this is a result of endogenous settlement patterns of refugees. Once we account for the endogeneity using a plausibly exogenous instrument, we find no evidence of an effect on native mortality for any age group. We also analyze the pressure that the refugees put on the health care services in Turkey, as well as the government's response, to understand our findings on mortality outcomes.
\end{abstract}

Keywords: refugees; health care infrastructure; native mortality; infant; child; elderly; instrumental variables

JEL Codes: H51; I18; J13; J15; O15 


\section{Introduction}

Millions of people around the world are forced to leave their country or region of residence due to military conflicts and natural disasters. According to the recent numbers provided by the UNHCR (2020), there are 70.8 million forcibly displaced people in the world, of which 41.3 million are internally displaced, 25.9 million are refugees, ${ }^{1}$ and 3.5 million are asylum-seekers. Due to the civil war that has been going on since 2011, Syria is currently the top source-country of refugees (6.7 million refugees) and its northern neighbor, Turkey, is the top refugee-hosting country (3.7 million refugees as of 2020). ${ }^{2}$ In this study, we examine the effects of the Syrian refugees in Turkey on the health infrastructure and the mortality outcomes of natives with a focus on neonatal, infant, child, and elderly mortality as of the end of 2017.

Forced migration has important implications for the communities that host the migrants, as well as for the people that move. ${ }^{3}$ However, very little evidence exists on the impact of forced migrants on the health outcomes of the communities in the hosting regions, ${ }^{4}$ although the effects of forced migration on the health outcomes of migrants have been studied more often. ${ }^{5}$ Moreover, the

${ }^{1}$ The impact of refugees is mostly realized not by developed countries but by countries neighboring the countries of origin of refugees; in fact, 80 percent of refugees reside in neighboring countries (UNHCR, 2020).

${ }^{2}$ Officially, Syrians in Turkey do not have refugee status officially but are under "temporary protection". For a discussion of the legal status of Syrian refugees in Turkey, see İçduygu (2015).

${ }^{3}$ Several studies examine various effects of forced migration on the hosting communities; see, e.g.., Aksu et al. (2018), Alix-Garcia and Bartlett (2015), Calderon-Mejia and Ibanez (2016), Ceritoglu et al. (2016), Fallah et al. (2019), Maystadt and Verwimp (2014), Morales (2018), Ruiz and Vargas-Silva (2016) for labor market effects, Akgunduz et al. (2018), Alix-Garcia et al. (2018), and Altindag et al. (2020) for local production effects, Alix Garcia et al. (2013) for environmental effects; Alix-Garcia and Saah (2010), Balkan and Tumen (2016), Depetris-Chauvin and Santos (2018) for price effects, and Maystadt and Duranton (2019) for effects on road infrastructure.

${ }^{4}$ This point is also made by Maystadt et al (2019) in their review article. Regarding the literature on the impact of refugees on health outcomes of natives, Ruiz et al. (2017) point out that the scarcity of data and the difficulty of measuring the potential effects and interpreting the results as causal effects of refugees are the major obstacles.

5 See, for instance, Akresh et al. (2012), Avogo and Agadjanian (2010), Bundervoet et al. (2009), Guerrero-Serdán (2009), Guha-Sapir and Gijsbert (2004), Hargreaves et al. (2004), Khawaja (2004), Madi (2000), Minoiu and Shemyakina (2014), Singh et al. (2005a, 2005b), Verwimp and van Bavel (2005). 
literature on the link between refugee influxes and health outcomes in the hosting regions has mostly established associations rather than causal relationships. Among the very few studies that establish a causal relationship, Montalvo and Reynal-Querol (2007) show that mass population movement from a country with high prevalence of malaria has a significant impact on the number of malaria cases in the refugee hosting countries, using panel data on 135 countries. ${ }^{6}$ However, Maystadt et al. (2019) note that this finding is restricted to the sample of tropical countries in that study and cannot be generalized to all refugee-hosting countries. Baez (2011) examines the health effects of the massive migration in 1994 from Burundi and Rwanda to the region of Kagera in Tanzania. Using micro-level data from the Demographic and Health Surveys, Baez examines the causal effects of refugee intensity on a rich set of health outcomes of local children. The author's instrumental variable estimates indicate a 7-percentage-point increase in child mortality. To the best of our knowledge, this is the only study that estimates the causal effect of a refugee shock on mortality outcomes in the hosting community. Certainly, more research is needed to understand the causal effect of the refugee shocks on the health outcomes of hosting communities. ${ }^{7}$

As a result of the war that started in Syria in 2011, 3.4 million Syrian refugees arrived in Turkey as of the end of 2017. The war caused substantial destruction of the health infrastructure in Syria. During the war, many internally displaced Syrians were subject to epidemic diseases including hepatitis A, typhoid fever, and cholera, as well as non-communicable ones, due to poor sanitary conditions (WHO, 2013; Petersen et al., 2013; Cousins, 2015). Moreover, these diseases posed a risk to neighboring countries as internally displaced people started arriving there. In fact, infectious diseases were reported in Jordan, Lebanon, Iraq, and Turkey (WHO, 2013), including reports of

\footnotetext{
${ }^{6}$ Other studies report associations between large refugee inflows and the spread of infectious diseases such as malaria (Kalipeni and Oppong, 1998; Kazmi and Pandit, 2001). However, Gallup and Sachs (2001) outline the potential econometric challenges in interpreting the impact of a large and sudden refugee influx on the spread of malaria. In particular, the authors highlight that the measurement of malaria incidence in a population is very difficult as there is no clear methodology to diagnose malaria.

${ }^{7}$ A scant literature also exists on the effects of migrants in developed countries on the health outcomes of natives. Giuntella and Mazzonna (2012) find that immigrants in Germany in fact improve the health status of natives primarily. This arises from the fact that immigrants replace natives who work in more difficult and risky occupations (Orrenius and Zavodny, 2009, 2012; Giuntella, 2012).
} 
nosocomial infection, viral hepatitis, cutaneous leishmaniasis, tuberculosis, and measles in Turkey (Leblebicioglu, 2016; Ekmekci, 2017).

Turkey has universal health coverage for its citizens and has implemented a generous health care policy toward Syrian refugees. Registered Syrian refugees have been integrated to the universal health coverage system of Turkey in the same way as native residents; hence have access to public primary, secondary and tertiary health care services free of charge. Unregistered Syrian refugees can use preventive and emergency services for free. Most Syrian refugees are registered as this allows them to use all health and education services of the state and is a precondition for receiving Emergency Social Safety Net (ESSN) cash transfers.

The arrival of refugees could impact natives' health outcomes via a number of channels. First, the arrival of such a high number of refugees means that there will be more potential patients per health-care resources, in the absence of investment in these resources. Ozdogan et al. (2014) report that thousands of seriously injured patients were brought to Turkey from Syria for emergency operations and postoperative intensive care. ${ }^{8}$ Moreover, several studies report that refugees have a high incidence of health care utilization in Turkey as a result of injuries, poor living conditions, and lack of access to health care services in their home country (Turkish Disaster and Emergency Management Authority, 2017; Ekmekci, 2017; Savas et al., 2016). In addition, Syrian refugees have high birth rates; in fact, according to the 2018 Turkish Demographic Health Survey, the fertility rate of Syrian women is 5.3 compared to 2.3 for native women. Poor health conditions of refugee mothers imply that their infants could also face adverse health consequences. The government's capacity to manage the increase in the demand for health services is critical here (Porignon et al. 1995, Goyens et al. 1996, Whitaker 2002)—which we examine in this study.

Second, Syrian refugees faced certain infectious diseases during their exodus and arrived in Turkey with them. In fact, as reported above, certain disease outbreaks took place in Turkey. Third, the arrival of refugees could affect native health indirectly through their economic impact. Aksu et al. (2018) show that the arrival of refugees caused substantial displacement of natives working in the informal sector (although some of these transferred to jobs in the formal sector). They also report

\footnotetext{
${ }^{8}$ Savas et al. (2016) provide evidence from a university hospital in Hatay, a Turkish province bordering Syria, that refugees increased health care providers' workloads and patients' waiting time.
} 
an increase in consumer prices. Consequently, poverty might increase among certain native groups — worsening their own and their children's health conditions. ${ }^{9}$

In this paper, we focus on neonatal, infant, child and elderly mortality because these are the most vulnerable groups. The high fertility rate of Syrian refugees could put a disproportionate strain on the health system for infants and children. For instance, they could cause congestion at neonatal intensive care units for the most vulnerable infants. Although Turkey has significantly lowered its infant and child mortality in the last 30 years, they remain significantly above those in high income countries. In 2011, before the refugees started arriving, the infant mortality rate in Turkey was 13.9 per 1,000 births compared to 4.9 in high income countries. The quality of health infrastructure in Turkey in terms of human resources (doctors, nurses, and midwifes per capita) and physical resources (hospital beds per capita, etc.), as well as health expenditures per capita, is similar to those in other middle income countries, but significantly below that in high income countries.

For our empirical analysis, we combine several administrative data sources. Mortality data for the 2009-17 period come from the Central Civil Registration System of Turkey (which was initiated in 2009). The data on reasons for mortality are drawn from the Death Notification System (DNS) of Turkey. All mortality data in this study cover only the permanent residents of Turkey, hence exclude the refugees. We also use data on the human and physical infrastructure of the health system provided by the Turkish Ministry of Health. We combine these data sources with data on province-level characteristics over time obtained from the Turkish Statistical Institute (TurkStat). To identify the impact of the migrant shock on these health outcomes, we exploit the provincial variation in the ratio of refugees to natives in a difference-in-differences regression. Since this variation across provinces could be endogenous due to refugees' choice of settlement patterns, we use an instrumental variable strategy. Our instrument, which is based on geographic distance, also accounts for the potential endogeneity in the level and timing of the arrival of refugees in Turkey. Our results show that the arrival of refugees in fact put a significant pressure on the health care infrastructure - despite evidence of investment in certain elements of the infrastructure by the

\footnotetext{
${ }^{9}$ In the context of refugees in Tanzania, Maystadt and Verwimp (2014) find that while some natives (self-employed farmers) benefit economically from the refugee inflow, others (agricultural workers) are adversely affected due to a labor market competition and higher prices on the commodity markets.
} 
Turkish government. The government increased the number of nurses, pediatricians, and hospital beds in the hosting regions. However, this was not sufficient to keep all resources per person (native and refugee) at the levels before the refugee influx. The numbers of doctors, midwifes, hospitals, and adult intensive care beds all decline in per-capita terms. Moreover, the magnitude of this decline is significant in some cases. For instance, we estimate that a 10 percentage-point increase in the refugee-to-native ratio decreases the number of doctors per person by about 9 percent.

In terms of the impact of the refugee shock on natives' mortality, the OLS estimates provide suggestive evidence that the refugee shock increases neonatal, infant and child mortality. However, this results from the endogenous settlement patterns of refugees; the 2SLS estimates indicate no evidence of the migrant shock on neonatal, infant, child, or elderly mortality. This implies that refugees are more likely to settle in provinces for which, in the absence of the refugee shock, mortality outcomes would exhibit a more negative trend over time.

The key contribution of this study is that, to the best of our knowledge, it examines the impact of a massive refugee shock on natives' health outcomes in a middle income country for the first time and anywhere in the world for the second time. While Baez (2011) finds a negative impact of the refugee shock on child mortality in a low-income country, we find no evidence of such an adverse effect in a middle-income country despite the bigger magnitude of the refugee shock and more variation in the key variable of interest. ${ }^{10}$ Moreover, while Baez focuses on child mortality, our study examines adult as well as child mortality. Our results imply that the health infrastructure of a middle-income country-despite the evidence on the worsening of several health inputs in percapita terms due to the arrival of refugees - was able to cope much better with the refugee shock, highlighting the importance of the existing health infrastructure in handling the pressure of a massive influx of refugees.

The rest of the paper is organized as follows. The next section provides background information. Section 3 describes the data and Section 4 the identification method and estimation. The results are given in Section 5. Several robustness checks are provided in Section 6. Section 7 concludes.

\footnotetext{
${ }^{10}$ We use the variation in the intensity of refugees across regions rather than a dummy treatment status.
} 


\section{Background Information}

\subsection{Mortality Outcomes and Health System Infrastructure in Turkey}

First, we provide background information on mortality outcomes and the health system infrastructure in Turkey in order to understand the preparedness of the existing health capacity to the massive refugee inflow. Figure 1 displays the evolution of several health outcomes in Turkey, in comparison to the averages of those in lower-middle income, higher-middle income, and highincome countries.

In 2011, before the Syrian refugees started arriving in, the infant mortality rate in Turkey was 13.9 per 1,000 births. While this is significantly lower than that in low income countries (at 59.1), it is much higher than that in high income countries (at 4.9). In fact, the rate in Turkey was similar to that for upper-middle income countries (at 15.0) to which Turkey belongs. These patterns are very similar for child mortality and neonatal mortality. ${ }^{11}$ It is also important to point out the strong downward trend in child, infant, and neonatal mortality rates in Turkey over time. For instance, while the infant mortality rate in Turkey in 1990 was 55.4 (compared to 40.6 for upper middle income countries and 10.4 for high income countries), it was only 13.9 in 2011 and in par with the average in upper middle income countries. The patterns over time have been similar for child and neonatal mortality.

As can be seen in the second row of Figure 1, the number of physicians per 1,000 people in Turkey in 2011 (before the refugees arrived) is around 1.5 and similar to the average for upper-middle income countries. This is significantly below the average for high income countries (about 2.5) but higher than the average for lower-middle income countries (about 0.5). The number of nurses and midwives per 1,000 people in Turkey in 2011, at just above 2, is slightly below the level in uppermiddle income countries but much lower than that in high income countries (which is almost 10). The number of hospital beds per 1,000 people in Turkey in 2011 is also between the levels for upper-middle income and lower-middle income countries, but much lower than that in high income

\footnotetext{
${ }^{11}$ While the neonatal mortality rate was 9.1 in Turkey in 2011 (which is exactly equal to the average for upper middle income countries), it was 31 for low income countries, but only 3.2 for high income countries.
} 
countries. The first graph in the third row of Figure 1 shows a big gap in health expenditures per capita at PPP between high income countries and Turkey, as well as other middle income countries. Since the 2000s, the Turkish government has implemented several health system reforms under the Health Transformation Program (HTP). A major part of HTP was the Family Medicine Program (FMP), which was first introduced in 2005 in a single province and gradually implemented across all 81 provinces until 2010. According to this program, every resident is assigned a family physician and Family Health Centers, where family physicians and nurses/midwives work, are established in all neighborhoods. The health workers in these centers are employed by the state and their services are free of charge to all residents. Goals of these centers include the monitoring of pregnant women and infants, including infants' immunizations. In fact, as can be seen from the last row of Figure 1, a significant rise in immunization (HepB3, DPT, and measles) of children in Turkey is observed. Prior to this program, immunization rates in Turkey were somewhat below that in upper middle income countries and well below that in high income countries. However, after the program, they became as high as that in high income countries. Finally, as can be seen from the third row of Figure 1, also during the period the FMP is implemented, a significant rise is observed in the fraction of women receiving antenatal care and the fraction of births attended by skilled health staff. Cesur et al. (2017) find that the FMP program lowered the mortality rates among infants and the elderly. Essentially, Turkey significantly bolstered its health system, particularly on infant and mother health, before the realization of the massive refugee influx from Syria.

\subsection{Arrival of Refugees, Their Health Status and Integration in the Health System in Turkey}

The civil war in Syria, started in 2011, forced approximately 7.5 million Syrians to leave their home country and became the world's largest forced migration crisis in the 21 st Century. ${ }^{12}$ Turkey has been the largest recipient of Syrian refugees due to its geographic location and about 3.4 million Syrian refugees lived in Turkey as of the end of 2017 (UNHCR). Ferris and Kirişci (2016) report that most of the refugees stated that they left Syria for security reasons and chose Turkey as their

\footnotetext{
${ }^{12}$ See Ferris and Kirişci (2016) for a discussion on the political events that resulted in the mass migration of Syrians.
} 
destination due to the ease of transportation. The Turkish government has implemented an opendoor policy for the refugee population and Syrian refugees are given a temporary residence permit mainly for health, work, and schooling purposes. During the early phases of the refugee inflow, the Turkish government set up 21 camps in 10 provinces, which housed over 210,000 refugees by December 2013. The number of Syrian refugees in Turkey was 560,129 at the end of 2013. This number reached $1,622,839$ by the end of 2014 and 2,397,725 by the end of 2015 . Over time, many refugees settled in urban areas, and only about $10 \%$ of Syrians in Turkey lived in refugee camps at the end of 2015 (Turkish Directorate General for Migration Management, 2016). The number of Syrian refugees in Turkey kept increasing even after 2015 (unlike those in other neighboring countries of Iraq, Lebanon, and Jordan) and reached 2,802,699 by the end of 2016 and 3,404,451 by the end of 2017 (UNHCR).

During the civil war in Syria, the health profile of Syrian people was exposed to a tragic transition. Many Syrians including the health staff were subject to serious physical and mental health problems causing a growing number of people in great need of treatment and medical interventions (Kherallah et al., 2012). The armed conflict caused substantial destruction to the health care infrastructure in Syria and public health challenges including serious maternal and child health problems. WHO (2013) reports that in 2013, two years after the start of the civil war, at least 35\% of country's public hospitals were out of service and $70 \%$ of health workforce left the country in some provinces. WHO (2013) also reports that many internally displaced people lived in poor sanitary conditions due to limited access to health care services, pharmaceuticals, and clean water-which increases the risk of epidemic diseases. Petersen et al. (2013) report increased cases of cutaneous leishmaniasis (a disease transmitted to humans through sand fly bites) for internally displaced Syrians. Moreover, Syrian people were exposed to several non-communicable and other infectious diseases such as malnutrition, tuberculosis, scabies, bronchiolitis, acute watery diarrhea, hepatitis A, cholera, typhoid fever, and vaccine-preventable diseases such as measles during the military attacks in their home country (Cousins, 2015; Ozaras et al., 2016a; Savas et al., 2016). Ozaras et al. (2016a) report that after a 15-year polio-free period, a poliomyelitis outbreak of 37 cases was reported in 2013.

Soon after the war began, WHO (2013) warned about an increased risk of disease epidemics in Syria threatening the neighboring countries. WHO stated that measles, tuberculosis, and cutaneous 
leishmaniasis had been reported among displaced Syrians in Jordan, Lebanon, Iraq, and Turkey. ${ }^{13}$ Refugees who were displaced from Syria arrived in Turkey in great need of health care as a result of injuries, poor living conditions, and lack of access to health care services in their home country (Turkish Disaster and Emergency Management Authority, 2017). Moreover, cutaneous leishmaniasis, measles, hepatitis A, tuberculosis, malaria, and smallpox were reported in and out of the refugee camps within the borders of Turkey as common infectious diseases with a high incidence among the Syrian refugees (Ozaras et. al, 2016a; Leblebicioglu, 2016; Ekmekci, 2017). Turkey has implemented a very generous health care policy for Syrian refugees differently from the other major host countries in the region such as Lebanon, Jordan, and Egypt. ${ }^{14}$ The Turkish government provides primary, secondary and tertiary health care services for Syrian refugees in their province of registration. Current legislation meets all medical requirements of Syrian refugees and treatment costs are billed to the Governor of the relevant province. Registered Syrian refugees are entitled to be holders of universal health coverage and health care services offered to Syrian refugees by the universal health coverage system are the same as the health services provided to Turkish native population. ${ }^{15}$ Essentially, all Syrian refugees in Turkey are able to use preventive

13 Alawieh et al. (2014) report that the sudden increase in cases of leishmaniasis in Lebanon in 2013 was due to the increasing number of Syrian refugees. Ozaras et al. (2016b) report a cholera outbreak among the Syrian refugees in Iraq.

${ }^{14}$ Syrian refugees in Lebanon have restricted access to health care services including maternal and child health services in public centers (Akram et al., 2015). Public centers mostly provide health care services to the poorest portion of the Lebanon society. Higher quality health care services in Lebanon are provided by private health centers in which Syrian refugees do not have free access to health services. Syrian refugees in Jordan have to pay for their own health care expenditures in order to benefit from primary, secondary and tertiary health care facilities as of November 2014 (Doocy et al., 2016). Registered Syrian refugees in Jordan were able to use health care services free of charge until November 2014, but the government was not able to keep offering free access to health care services to Syrian refugees following a sharp increase in the costs of health care services after this date. In Egypt, the Ministry of Health provides Syrian refugees free access only to primary health care services, Syrian refugees need to pay for the secondary and tertiary health care expenditures (Joint Assessment for Syrian Refugees in Egypt, 2013). In fact, 42.56\% of Syrians paid all of their health care expenditures, $41.92 \%$ made partial payments for their health care, and $15.92 \%$ had an access to free health services.

${ }^{15}$ Syrian patients have to pay only a small amount of contribution fee for each visit using the universal insurance and 
and emergency services for free and registered refugees have an access to public primary, secondary and tertiary health care services free of charge. In addition, Refugee Health Centers have been established in certain districts, which employ also Syrian health personnel as well as bilingual health workers.

The arrival of a massive refugee group with existing health problems certainly put the health care infrastructure in Turkey under pressure. Moreover, language barriers and continuous mobility of Syrian refugees from one province to the other have created additional difficulties in health care provision to them (Mardin, 2017). Savas et al. (2016) use a survey to explore the impact of Syrian refugees on the health care providers' workload at a university hospital in Hatay, a Turkish province bordered by Syria. Their results point out to an increase in health care providers' workloads and patients' waiting time due to the density of refugee patients. The study also finds the capacity of intensive care services to be insufficient. Moreover, the study reports that the incidence of complications is more frequent in refugee patients due to serious infectious and noncommunicable diseases and thus their need for inpatient care and intensive care is higher than that of native Turkish patients. ${ }^{16}$ Other studies also report that the high level of health care utilization among Syrian refugees caused capacity problems in overcrowded hospitals and reduced accessibility to health care services in the border provinces (Center for Middle Eastern Strategic Studies, 2015; Ekmekci, 2017). ${ }^{17}$ A WHO report (2019) notes that Syrian refugees account for 30 40 percent of patients in state hospitals in Turkish provinces near the Syrian border. Hence, health care services in the border provinces with a high ratio of refugees face substantial pressure.

\footnotetext{
Disaster and Emergency Management Authority of Turkey pays the contribution fee for the Syrians.

${ }^{16}$ A WHO survey (2019) finds that $15.2 \%$ of Syrian refugees in Turkey suffer from a chronic disease while another WHO survey (2016) reports that more than half of Syrian refugees are at high risk of developing a chronic disease.

17 Ekmekci (2017) states that native Turkish citizens complained about Syrian refugees for their frequent use of healthcare resources and they argued that those refugees were preventing the natives from using health care services when needed.
} 


\section{Data}

We combine a number of data sources for our empirical analysis. First, we use data on mortality numbers from the Turkish Statistical Institute (TurkStat), which draws this data from the Central Civil Registration System of Turkey (Merkezi Nufus Idaresi Sistemi, MERNIS). This dataset is at the province level including 81 provinces of Turkey and available annually from 2009 to 2017. It includes only native Turkish permanent residents, excluding Syrians under temporary protection. This dataset provides information on mortality numbers by age, as well as mortality numbers by month for infants and by weeks in the neonatal period. These information in the MERNIS system are obtained from the death declaration forms. These forms are filled by health workers for deaths taking place in a health center and transferred to District Directorate of Population within 10 days (which shares them with MERNIS). For deaths taking place out of a health center, District Directorate of Population is informed by the government employee who issues the death certificate. Second, we use TurkStat's age-specific province level population data to calculate age-specific mortality rates and also TurkStat's province level birth data to calculate infant and child mortality. Province level age-specific population data are based on Address Based Population Registration System (ABPRS) population census of TurkStat. All addresses within the boundaries of Turkey are registered in this system and all Turkish citizens are linked to the census via their national identification number. Using the information on number of deaths and population by age groups, we construct the aggregate mortality rate as well as the age-specific mortality rates for the $65+$ and $75+$ age groups. Since the calculation of infant and child mortality requires birth data, we use province-level birth data from TurkStat. TurkStat obtains birth data also via MERNIS, which registers births to an online database in reference to a birth certificate or a family's statement. All mortality rates are given per 1,000 people.

Third, for a separate analysis, we use data on reasons of death also obtained from TurkStat. The source of information for this data is the Death Notification System (DNS) of Turkey, which collects information coming from the death certificates filled by the physicians in hospitals, family health centers, institutions of municipal medicine, institutions of forensic medicine, and other health institutions. The diseases are coded according to International Classification of Diseases (ICD-10). This dataset is also available at the province-year level. 
Fourth, also for a separate analysis to check the impact of refugees on the health system, we use data on the health infrastructure in Turkey. As measures of the human capital part of the health infrastructure, we use the numbers of doctors, nurses, midwives, and pediatricians. As measures of the physical health infrastructure, we use the number of hospital beds, adult intensive care units, and neonatal intensive care units. The source of these data is the Turkish Ministry of Health, which collects them annually through the administrative records. By dividing these numbers on health inputs by the population — including refugees — we generate measures of the capacity of health infrastructure per person.

Throughout our empirical analysis, we account for different characteristics of provinces by using detailed information on their demographic, economic and health market characteristics, all of which are obtained from TurkStat. The demographic characteristics we use include the ratios of women with different levels of education (no degree, primary or secondary school, high school, and university or higher), the average household size, literacy rate, the fraction of women never married, and the average first-marriage age for women. Marriage statistics come from the information obtained from municipalities following each marriage and stored in MERNIS. The ABPRS is the source of the province level educational attainment and literacy rate statistics. Province-level never-married ratios and average household size data are also based on ABPRS. Finally, we use GDP per capita at the province level as provided by TurkStat in 2009 prices.

We combine these province-level data with data on the number of Syrians across the 81 provinces of Turkey from 2009 to 2017, excluding the year 2012 as a result of missing data on the distribution of Syrians across provinces. The Disaster and Emergency Management Authority (2013) provides information on the number of Syrian refugees for 2013. The number of refugees across provinces for 2014 is taken from Erdoğan (2014), who draws on information from the Ministry of Interior. Finally, the numbers for 2015-2017 are provided by the Directorate General of Migration Management. The total number of Syrians in Turkey varies considerably from month to month in a given year. For this reason, we make an adjustment on the variation of Syrians across provinces so that it can represent the year average instead of the end of year. ${ }^{18}$

\footnotetext{
${ }^{18}$ Averaging the monthly values on the total number of Syrians in Turkey (obtained from the UNHCR), we calculate the number of Syrians for each year. Then, we rescale the numbers of Syrian refugees across provinces (obtained from
} 


\subsection{Descriptive Statistics}

Table 1 presents descriptive statistics for the variables used in our empirical analysis. Infant and child mortality outcomes are given per 1,000 births whereas adult mortality outcomes are given per 1,000 people. The average mortality rate for all age groups in our sample is 5.8. Significant variation is observed across provinces and time, while the minimum value of average mortality rate is 2.7 , the maximum value is 10.2 . As expected, elderly and child mortality rates are much higher. The mortality rate for the $65+$ age group is above 44 and that for the $75+$ age group is above 78 , while the mean child mortality is 13.7 and the mean infant mortality is 11.0. In other words, about 80 percent of child mortality takes place within the first age. Also, a significant fraction of infant mortality is neonatal mortality, about 65 (7.13/11.0) percent of infant mortality takes places within the first month. In turn, of neonatal mortality, a large fraction, $70(5.0 / 7.1)$ percent, is early neonatal mortality. Substantial regional variation exists in infant and child mortality within the time period of our analysis. Child mortality ranges between 4.1 and 31.8 whereas infant mortality ranges between 0.94 and 18.6. The health infrastructure variables, as well as the socioeconomic characteristics of provinces, also exhibit substantial provincial variation within the 8-year frame of the data.

Figure 2 displays the ratio of refugees to natives across provinces for every year from 2013 to 2017 on a map of Turkey. The shade gets darker as the ratio increases. In 2013, the shaded provinces are all on or close to the Syrian border. Over time, however, the refugees disperse to the other regions of the country, particularly to the industrial major cities of western Turkey such as Istanbul, Kocaeli, Bursa, and Izmir. Nonetheless, even in 2017, the darkest shaded provinces are still on or close to the Syrian border. This implies that distance to the border is a very important factor determining the settlement patterns of refugees across Turkey — which is important in our definition of the instrumental variable.

Turkish sources that account for the numbers at the end of the year) so that they add up to the year average. 


\section{Identification Method and Estimation}

To estimate the refugee impact on inputs in the health sector and native mortality, we use a difference-in-differences methodology where we compare the provinces with high refugee intensity with those with low refugee intensity before and after the arrival of refugees. We use the following equation

$$
y_{p t}=\alpha+\beta \text { ratio }_{p t}+X_{p t} \Gamma+\delta_{p}+\theta_{t}+\mu_{p^{\prime} t}+\varepsilon_{p t},
$$

where $y_{p t}$ denotes the dependent variable in province $\mathrm{p}$ at time $\mathrm{t}$ and ratio ${ }_{p t}$ is the refugee-tonative ratio in province $\mathrm{p}$ at time t. In equation (1), $X_{p t}$ stands for other province-time level characteristics, $\delta_{p}$ for province fixed effects, and $\theta_{t}$ for time fixed effects. Province fixed effects capture the significant (time-invariant) variation across provinces in health inputs and mortality outcomes, shown in descriptive statistics. We also allow the time effects to vary across regions defined at various levels using region-year interactions $\left(\mu_{p^{\prime} t}\right)$. This allows us to partially capture the time-variant differences across provinces. Finally, $\alpha$ stands for the constant term and $\varepsilon_{p t}$ for the error term.

The dependent variables in equation (1), $y_{p t}$, include measures of inputs into the health system such as the numbers of doctors, nurses, midwifes, pediatricians, ${ }^{19}$ hospital beds, and intensive care units per person (native and refugee) as well as several measures of mortality outcomes by age (only for natives). In equation (1), the time-varying province level characteristics $\left(X_{p t}\right)$ include the fraction of women with various degrees of education (no degree, primary or secondary education, high school and university or higher degree), the fraction of never-married women, the average age of first-marriage for women, average household size, literacy rate, and GDP per capita. We use weighted regressions using age-specific province populations or number of births by province according to the dependent variable. ${ }^{20}$

\footnotetext{
19 This includes physicians with pediatric subspecialties such as pediatric cardiology, pediatric neurology, pediatric oncology etc. in addition to practicians of general pediatric care.

${ }^{20}$ If we had individual-level data, we could run these regressions at the individual level where the key variable of interest is again the ratio of refugees-to-natives. Therefore, we could interpret our regressions, where province-level
} 
A potential identification problem is that refugees' settlement patterns could be correlated with health infrastructure and mortality outcomes. Refugees might not choose their location of residence based on the health facilities; however, they are more likely to choose them based on economic and employment conditions. But, in the Turkish case, we would expect the economic conditions of provinces to be correlated with health inputs and outputs. Hence, we use an instrumental variable approach to generate an exogenous variation in the settlement patterns of refugees, where our instrument is distance based. ${ }^{21}$

As can be seen in Figure 2, although Syrian refugees migrate to the more developed urban centers of western Turkey over time, a higher fraction remain in the border region even in 2017-which indicates a strong role for distance in their settlement patterns. The first and obvious reason for this fact is that this border region is the entry point of the refugees, where camps were set up immediately after their arrival. Since they were thought to be temporary at first, the camps were established in areas close to the border. Even after the refugees left the camps for urban areas, many preferred to stay in the provinces that are close to their original region of residence in Syria, where many of their family members still resided. In fact, they are able to visit their family members in certain occasions like religious holidays. Finally, Syrians refugees in Turkey are supposed to use the health and educational facilities in the province they are registered. Although this is not strictly enforced, it might have created some inertia against further movement.

We employ the instrument used by Aksu et al. (2018), which is an extension of the instrument used by del Carpio and Wagner (2016). Essentially, the del Carpio-Wagner instrument distributes the Syrian refugees in Turkey in each year across Turkish provinces according to the distance of each Turkish province from each Syrian province and the pre-war population shares of Syrian provinces. However, Aksu et al. (2018) note that many Syrian refugees left for other bordering countries of Syria - namely Lebanon, Jordan, and Iraq — and that we need to account for the distance of Syrian

\footnotetext{
data are used with province-level populations as weights, as an aggregation of these individual-level regressions to the province level.

${ }^{21}$ In the analysis of health input variables, the inclusion of the number of refugees in the denominator of the dependent variable results in a mechanical measurement error problem in the key variable of interest - the ratio of refugees to natives. However, our instrumental variable estimation also handles this problem.
} 
provinces to these countries as well. This is important for two different reasons. First, this extension will make the first-stage regression stronger because, for instance, a disproportionate amount of refugees in Turkey originate from Aleppo and Idlib - which are close to Turkey - than Damascus which is close to Lebanon, al-Suwayda which is close to Jordan, or Dar-al-Zor which is close to Iraq. Second, while most instruments using migrant shocks resulting from political events make the assumption that the level and timing of the arrival of migrants are exogenous, our instrument does not make this assumption. This is more important in our context because there are different countries to choose from for the refugees. Hence, the level and timing of the refugees arriving in Turkey might not be exogenous. Therefore, we define the instrument as follows

$$
I_{p, t}=\sum_{S=1}^{13} \frac{\left(\frac{1}{d_{s, T}}\right) \pi_{s}}{\left(\frac{1}{d_{s, T}}+\frac{1}{d_{S, L}}+\frac{1}{d_{S, J}}+\frac{1}{d_{S, I}}\right)} \frac{T_{t}}{d_{p, s}},
$$

where $I_{p, t}$ stands for the expected number of refugees in province $\mathrm{p}$ at time $\mathrm{t}$ (the instrument) and $d_{s, T}, d_{s, L}, d_{s, J}$, and $d_{S, I}$ stand for the distance of Syrian province $\mathrm{s}$ to the closest border entry in Turkey, Lebanon, Jordan, and Iraq respectively. In equation (2), $\pi_{s}$ is the pre-war population share of Syrian province $\mathrm{s}, d_{p, s}$ is the distance of Turkish province $\mathrm{p}$ to Syrian province $\mathrm{s}$, and $T_{t}$ stands for the total number of Syrian refugees in the bordering four countries. Essentially, equation (2) is different from the del Carpio and Wagner instrument in two ways. First, the pre-war population shares of Syrian provinces are reweighted according to their distance from the four countries. For instance, while the pre-war population share of Aleppo is 0.21 , with the scaling in equation (2), its prewar population share (for Turkey) increases to 0.45 . Second, instead of allocating the number of refugees in Turkey, we allocate the total number of refugees in the four neighboring countries over time. Hence, this instrument accounts for the potential endogeneity of the level and timing of Syrian refugees entering Turkey.

\subsection{Identification Assumptions}

The identification assumption in our instrumental variable approach is that our distance-based instrument is not correlated with the unobserved trends in our dependent variables on health outcomes. This could fail, for instance, if our instrument is correlated with the unobserved trends in economic and employment conditions, hence with the unobserved trends in mortality outcomes. In fact, the more developed western regions of the country are far away from the Syrian border. If 
the more developed regions have different time trends in mortality outcomes than less developed regions, our identification assumption could fail. When we use time-region interactions $\left(\mu_{p^{\prime} t}\right)$, our instrument relies on a weaker independence assumption. For instance, when we use region-year fixed effects, we impose an independence assumption on the instrument within regions. In other words, in this case our identification assumption is that distance is not correlated with unobserved determinants of economic conditions and hence mortality — within the five regions of the countrywhich is a more plausible assumption.

Next, we provide support for this identification assumption. We conduct placebo regressions where we examine the effect of refugees when no effect is supposed to be observed. For this purpose, we restrict our data to the pre-shock period, 2009-2011 and assign the 2017 distribution of our instrument and the refugee-to-native ratio across provinces to 2011 and run a 2SLS regression. In other words, we act as if the refugees in 2017 arrived in 2011. If the instrument were correlated with unobserved pre-shock trends in mortality outcomes-contrary to the identification assumption - this regression would yield a statistically significant coefficient for the refugee intensity which is instrumented. We also implement similar analysis for health infrastructure variables.

The results of this placebo regression on the health infrastructure variables are given in Table 2 . No evidence exists for a correlation between the instrument and pre-shock trends for any of the variables and any of the specifications. ${ }^{22}$ Table 3 presents the results of the placebo regressions on mortality outcomes. With the baseline specification, evidence of a correlation between the instrument and the pre-shock trends exists, at the 10-percent statistical significance level, for two of the 12 mortality outcomes. However, as we weaken the common time trend assumption across regions, in columns (2) and (3), this evidence also vanishes. Hence, our preferred specification is the one with region-year fixed effects, which not only passes the placebo tests for all dependent variables but also is more flexible.

\footnotetext{
${ }^{22}$ We cannot conduct these placebo regressions for pediatricians and adult and neonatal intensive care units as we have no data for the pre-shock period for these variables.
} 


\section{Results}

Before moving into our main results, we briefly discuss the results of our first-stage estimations. Obviously, our first-stage results vary by specification. However, we discuss them in general not to be repetitive. Throughout our main results, given in Tables 4 to 8 , we have strong first-stages. The F-statistic is generally lower for more flexible specifications. Nonetheless, the minimum Fstatistic — which is above 15 in our main results - is well above the recommended levels.

\subsection{Investment in Health System Infrastructure}

First, we examine how the Turkish government responded to the arrival of refugees in terms of investment in the health infrastructure of the refugee-hosting regions. To examine this, we run equation (1) where the dependent variable stands for various measures of human and physical capacity of the health infrastructure. In this analysis, we also use the population of each province in logarithmic form as an additional control variable because the dependent variable is not in per capita terms. The results are displayed in Table 4 in three different panels, which are grouped according to the sample size. We observe the dependent variables in panel (A) throughout our full panel period, from 2009 to 2017, whereas only from 2013 to 2016 in panel (B) and from 2014 to 2017 in panel (C) - due to a lack of availability of the dependent variables in the latter two panels for the other years.

As can be seen from the table, no evidence of an increase in the number of doctors exists with either the OLS or 2SLS estimates. In terms of the number of midwives, although the less flexible OLS specifications indicate evidence of an increase, none of the specifications with the 2SLS estimates indicates any evidence of a change. On the other hand, the numbers of nurses and hospital beds increase in the migrant-hosting regions, which holds for all specifications with the 2SLS estimates. Quantitatively, a 10 percentage-point increase in the refugee-to-native ratio brings about a 7-8 percent increase in the number of nurses and a 7.6-8.3 percent increase in the number of hospital beds. The results for the number of hospitals are more mixed. While the OLS estimates show evidence of an increase, the statistical significance of this finding vanishes with the 2SLS estimates as standard errors grow. Yet, the 2SLS results are marginally insignificant and the coefficient magnitudes are at least as large as those of the OLS estimates. Panel (B) of Table 4 reveals evidence of an increase in the number of pediatricians in the refugee hosting regions; 
moreover, the magnitude of this increase is even larger than those for nurses and hospital beds. On the other hand, panel (C) shows no evidence of a change in intensive care bed units either for adults or for infants. Nonetheless, it is important to note that despite the much smaller sample size here, the coefficient estimates for neonatal intensive care beds are quite large.

In essence, the results show that the Turkish government responded to the refugee shock by increasing the number of nurses, pediatricians, and hospital beds in the hosting regions. The magnitude of the rise in the number of pediatricians is particularly impressive.

\subsection{Effect of Refugees on the Health System Infrastructure}

Here, we examine the strain that the refugee shock puts on the health system infrastructure in Turkey. For this purpose, we calculate the human and physical capacity indicators used above in per capita terms. Here, the population in the denominator includes both natives and the refugees. Essentially, we examine whether the investment displayed in the previous subsection was sufficient to keep health care inputs in per capita terms at the pre-refugee-shock levels. The results are given in Table 5 in the same format as in Table 4.

Panel (A) shows that the arrival of refugees decreases the number of doctors per person and the number of midwives per person, according to both the OLS and the 2SLS estimates. According to the 2SLS estimates, a 10 percentage-point increase in the refugee-to-native ratio decreases the number of doctors per person by about 9 percent. While the number of nurses per person also falls with the arrival of refugees according to the OLS estimates, no such statistical evidence remains with the 2SLS estimates - as the standard errors grow, which is usual in 2SLS estimation. For the number of hospital beds per capita, no evidence of an impact of the arrival of refugees exists. These results are consistent with those in Table 4. The investment of the Turkish government in extra nurses and hospital beds prevents an adverse effect of the refugee shock on these inputs in per capita terms, whereas the numbers of doctors and midwives per capita fall.

We examine the effect of the refugee shock on the number of pediatricians per capita in panel (B) and on the number of intensive care beds per capita (separately for adults and neonatals) in panel (C). The change in the numbers of pediatricians and neonatal intensive care units per capita is particularly important in this study because we focus on infant and child mortality. While the OLS estimates indicate an increase in the number of pediatricians per capita, this evidence vanishes with 
the 2SLS estimates as standard errors grow. However, it is important to note that the magnitudes of the coefficients with the 2SLS estimates are similar to those with the OLS estimates. This finding is consistent with that presented in the previous subsection on the substantial increase in the number of pediatricians in the refugee-hosting regions. While no evidence of an effect of the refugee shock on neonatal intensive care units per capita exists, the results for adult intensive care units per capita are more mixed. While the coefficient in column (4) is close to zero, the negative coefficients with the more flexible specifications in columns (5) and (6) are much larger in magnitude and also statistically significant at the 10-percent level in column (5). In essence, as the number of potential patients increases with the arrival of a substantial number of Syrian refugees, the numbers of doctors, midwifes, and hospitals, as well as the number of adult intensive care units, do not keep up with this increase. Therefore, the numbers of these health inputs per person all decline.

\subsection{Effect of Refugees on Native Mortality}

Table 6 shows the refugee effect on native mortality for all ages and by age groups. The OLS estimates are given in columns (1) to (3) and the 2SLS estimates in columns (4) to (6) for alternative specifications on region-time effects. When we examine the results for infant and child mortality, we see that the OLS coefficients are consistently positive across specifications. Moreover, with the more flexible specification in column (3), the results become statistically significant for child mortality. However, when we examine the 2SLS estimates, we observe no evidence of the refugee shock increasing either infant or child mortality. Moreover, this lack of evidence is not simply due to a lack of precision; with our preferred specification, the absolute magnitudes of the 2SLS coefficients (in column (6)) are much smaller than those of the OLS coefficients (in column (3)). Essentially, the difference between the OLS and the 2SLS estimates suggests that refugees are more likely to settle in regions, where - in the absence of the refugee shock-infant and child mortality would have a more negative time trend. ${ }^{23}$ Even though we control for region-time fixed effects, we do this at a more aggregate region level. Within these aggregate-level regions - as the

\footnotetext{
${ }^{23}$ Another reason for the difference between the OLS and 2SLS estimates could be measurement error in the ratio of refugees to natives.
} 
comparison of the OLS and 2SLS suggests - refugees are more likely to settle in provinces where infant and child mortality would have a worse time trend in the absence of the arrival of refugees. When we examine the refugee impact on elderly mortality, we observe that the 2SLS coefficients are all positive but small in magnitude and not statistically significant at the conventional levels. The magnitudes of the coefficients become especially close to zero with our preferred specification with region-year fixed effects. Regarding overall mortality, as can be seen in column (4), the 2SLS estimates with the specification that makes the independence assumption for the instrument conditional on a common time-trend across provinces provide weak evidence that the arrival of refugees increases native mortality. However, with the other specifications in columns (5) and (6), which relax this assumption, this evidence vanishes. In fact, the coefficients become close to zero. Next, we dig deeper in terms of infant mortality. Table 7 presents the results on the refugee impact on infant mortality by months, weeks, and days. Similar to that in Table 6, the OLS estimates provide suggestive evidence of the refugee shock increasing neonatal mortality rates. With the most flexible specification in column (3), the coefficients are positive for all day- or month-specific mortality rates except for that at day zero. In fact, the coefficient for the post-early neonatal period (days 7-29) is statistically significant at the 10-percent level. However, when we account for the endogeneity in the settlement patterns of refugees via the 2SLS estimates, no evidence of refugees impacting neonatal or post-early neonatal mortality remains. This is not a result of high standard errors; with the preferred specification in column (6), the coefficient estimate of the 2SLS regression is close to zero.

While we find no evidence of a refugee impact on native mortality for any age group, refugees could still increase native mortality from specific reasons, such as infectious diseases given the backdrop of many refugees carrying these kind of diseases, as reviewed in Section 2. Therefore, we also examine the impact of the refugee shock on infant mortality among natives by reason of death. As can be seen from the estimation results presented in Table 8, no evidence is observed for an effect of the refugee shock on infectious diseases. Nor is there evidence of an effect on categories $\mathrm{A} \& \mathrm{~B}$, which include certain infectious and parasitic diseases. In addition, for category P (perinatal reasons), which accounts for the highest frequency of infant deaths, no evidence of an effect of the arrival of refugees is observed. 


\section{Robustness Checks}

\subsection{Alternative Regions}

We also assess the sensitivity of our findings to alternative regional restrictions. We take three alternative regions. First, we exclude the Istanbul region (NUTS-1 region 1), where almost every one person in five in Turkey live. Second, we exclude western Turkey (NUTS-1 regions 1-4), which is more developed than the rest of the country. Third, we include only eastern Turkey (NUTS-1 regions 10-12) and the Mediterranean region (NUTS-1 region 7); southeastern Turkey (NUTS-1 region 12) and the Mediterranean region have the highest ratios of refugees to natives, as can be seen from Figure 2. The estimation results are given in Tables A1 and A2 in the Appendix for health infrastructure variables and for mortality variables, respectively. The results in Table A1 confirm our previous finding on the negative effect of the refugee shock on the number of doctors, midwives, hospitals, and adult intensive care beds in per-capita terms. The precision of the estimates, however, gradually diminishes as we restrict the sample size from the main sample to sample (C). The results in Table A2 show no evidence of an effect of the refugee shock on mortality outcomes for any of the subsamples.

\subsection{Alternative Instruments}

Next, we examine the robustness of our findings to the use of an alternative instrument. Instead of our instrument that accounts for the three other neighboring countries of Syria as potential destinations, we take the simpler del Carpio-Wagner instrument, which distributes the Syrian refugees in Turkey across provinces according to their distances from Syrian provinces and the prewar shares of Syrian provinces. The results are given in Table A3 for health infrastructure variables and in Table A4 for mortality outcomes. The effect of the refugee shock on health infrastructure variables changes slightly with the alternative instrument. The fact that no evidence is observed for an effect of the refugee shock on natives' mortality outcomes for any age group also persists with the alternative instrument in Table A4.

\subsection{Alternative Specifications}

Finally, we analyze the sensitivity of our findings to the logarithmic transformation of the dependent variables. We do not make this transformation in the estimation results given in Tables 
A5 and A6 in the Appendix. Compared to the main findings in Table 5, the refugee effect on the number of hospitals per person becomes weaker whereas the negative effect on the number of nurses per person gets stronger. The other findings are similar. Regarding the effect on mortality outcomes, the results in Table A6 are similar to those in Tables 6 and 7. While the OLS results provide some suggestive evidence of an increase in post-early neonatal mortality and child mortality, these vanish with the 2SLS estimates.

\section{Conclusion}

This study examines the effects of the massive influx of Syrian refugees on the health system infrastructure and native mortality in Turkey. We find that the arrival of refugees strains the existing physical and human infrastructure of the health system substantially. In fact, several indicators - such as the numbers of doctors, midwives, hospitals, and adult intensive care units per capita-worsen. For instance, 10 percentage-point increase in the refugee-to-native ratio (as in several provinces) decreases the number of doctors per person by about 6-9 percent. This overcrowding of health care resources - as well as the findings of the previous literature on the rise in communicable diseases and the deteriorating economic conditions for certain groups of the native population due to the arrival of refugees - could imply an increase in mortality among the most vulnerable groups, such as infants, children, and elderly. Using rich administrative data that display variation at the 81-province level and geographical variation in the intensity of refugees across provinces - as well as a strong source of variation in it using a highly plausible instrumental variable - we, however, find no evidence of an adverse effect of refugees on native mortality for any age group.

This finding is different from that of Baez (2011) who finds a substantial negative effect of refugees on infant mortality among natives in a lower-income host country (Tanzania). This difference highlights the importance of the capabilities of the existing health care infrastructure. Although several indicators of these capabilities for Turkey lag significantly behind those in developed countries, they are still better than those in low-income countries. Despite the worsening in some of these indicators due to the massive refugee influx, they were apparently already at a sufficient level to cope with the arrival of millions of refugees. In addition, it is important to highlight the 
increase in the number of pediatricians in the refugee-hosting regions in understanding the lack of evidence of an effect on infant and child mortality.

Turkey was relatively well prepared to the refugee shock. It bolstered its health infrastructure before the arrival of refugees, in particular with regard to mother and infant health, via its Family Medicine Program implemented between 2005 and 2009. In fact, immunization rates reached the levels of those in high income countries. Moreover, Turkey has a universal health coverage system. On the other hand, refugees were integrated into this universal coverage, potentially straining the resources previously allocated for natives.

At the same time, this study also indicates a worsening of several health inputs per capita with the arrival of refugees. Although the Turkish government made certain investments in the healthsystem infrastructure of the refugee-hosting regions, these were not sufficient to keep many health inputs in per-capita terms at the pre-refugee levels. Even though this did not result a change in mortality rates, it could worsen the satisfaction of the native population from health services, as indicated by several qualitative studies. Hence, it is a critical challenge for low- and middle-income countries to respond to refugee shocks by strengthening their health system infrastructure. 


\section{References}

Akgunduz, Y.E., van den Berg, M. and W. Hassink (2018). "The impact of the Syrian refugee crisis on firm entry and performance in Turkey," World Bank Economic Review 32(1): 19-40.

Akram, M.S., Bidinger, S., Lang. A., Hites, D., Kuzmova, Y. and E. Noureddine (2015). Protecting Syrian Refugees: Laws, Policies, and Global Responsibility Sharing. Boston University Report.

Akresh, R., Lucchetti, L. and H. Thirumurthy (2012). "Wars and child health: Evidence from the Eritrean-Ethiopian conflict," Journal of Development Economics 99(2): 330-340.

Aksu, E., Erzan, R. and M.G. Kirdar (2018). "The Impact of Mass Migration of Syrians on the Turkish Labor Market,” IZA Discussion Papers 12050.

Alawieh, A., Musharrafieh, U., Jaber, A., Berry, A., Ghosn, N. and A.R. Bizri (2014). "Revisiting leishmaniasis in the time of war: the Syrian conflict and the Lebanese outbreak," International Journal of Infectious Diseases 29:115-9.

Alix-Garcia, J. and A. Bartlett (2015). "Occupations under fire: the labor market in a complex emergency," Oxford Economic Papers 67(3): 687-714.

Alix-Garcia, J., Bartlett A. and D. Saah (2013). "The landscape of conflict: IDPs, aid and land-use change in Darfur," Journal of Economic Geography 13(4): 589-617.

Alix-Garcia, J. and D. Saah (2010). "The effect of refugee inflows on host communities: evidence from Tanzania,” World Bank Economic Review 24(1): 148-70.

Alix-Garcia, J., Walker, J., Bartlett, A., Onder, H. and A. Sanghi (2018). "Do refugee camps help or hurt hosts? The case of Kakuma, Kenya," Journal of Development Economics 130: 6683.

Altindag, O., Bakis, O. and S. Rozo (2018). "Blessing or burden? The impact of refugees on businesses and the informal economy," Journal of Development Economics, forthcoming.

Avogo W.A. and V. Agadjanian (2010). "Forced migration and child health and mortality in Angola," Social Science and Medicine 70: 53-60.

Baez, J. (2011). "Civil Wars beyond Their Borders: The Human Capital and Health Consequences 
of Hosting Refugees," Journal of Development Economics 96: 391-408.

Balkan, B. and S. Tumen (2016). "Immigration and prices: quasi-experimental evidence from Syrian refugees in Turkey," Journal of Population Economics 29: 657-86.

Bundervoet, T., Verwimp, P. and R. Akresh (2010). "Health and Civil War in Rural Burundi," Journal of Human Resources 44(2): 536-563.

Calderon-Mejia, V. \& Ibanez A.M. (2016). Labour Market Effects of Migration-Related Supply Shocks: Evidence from Internal Refugees in Colombia. Journal of Economic Geography 16(3); 695-713.

Center for Middle Eastern Strategic Studies (ORSAM) (2015). "Effects of the Syrian Refugees on Turkey," ORSAM Report No: 195.

Ceritoğlu, E., Yüncüler, H.B., Torun, H., \& Tümen, S. (2017). The Impact of Syrian Refugees on Natives' Labor Market Outcomes in Turkey: Evidence from a Quasi-Experimental Design. IZA Journal of Labor Policy 6: Article number: 5.

Cesur, R., Gunes, P.M. and E. Tekin (2017). "The value of socialized medicine: The Impact of universal primary healthcare provision on mortality rates in Turkey," Journal of Public Economics 150: 75-93.

Cousins S. (2015). “Syrian crisis: health experts say more can be done," Lancet 385: 931-4.

Depetris-Chauvin, E. and R.J. Santos (2018). "Unexpected Guests: The Impact of Internal Displacement Inflows on Rental Prices in Colombian Host Cities,” Journal of Development Economics 134: 289-309.

Doocy S, Lyles E, Akhu-Zaheya, L., Burton, A. and G. Burnham (2016). "Health service access and utilization among Syrian refugees in Jordan," International Journal for Equity in Health 15(1): 108.

Ekmekci P.E. (2017). "Syrian Refugees, Health and Migration Legislation in Turkey,” Journal of Immigrant and Minority Health 19(6): 1434-41.

Erdoğan, M. (2014). Syrians in Turkey: Social Acceptance and Integration Research. Migration and Politics Research Centre, Hacettepe University.

Fallah, B., Kraft, C. and J. Wahba, (2018). "The Impact of Refugees on Employment and Wages in 
Jordan,” Journal of Development Economics 139: 203-216.

Ferris, E. and K. Kirişci (2016) The Consequences of Chaos: Syria's Humanitarian Crisis and the Failure to Protect, Brookings Institution Press, Washington, D.C.

Gallup, J.L. and J.D. Sachs (2001). "The economic burden of malaria," American Journal of Tropical Medicine and Hygene 64: 85-96.

Giuntella O. (2012). "Do immigrants squeeze natives out of bad schedules? Evidence from Italy," IZA Journal of Migration 1(7): 1-21.

Giuntella O. and F. Mazzonna (2015). "Do immigrants improve the health of natives?" Journal of Health Economics 43: 140-153.

Goyens, P., Porignon, D., Sorongane, E.M. and R. Tonglet (1996). "Humanitarian aid and health services in Eastern Kivu, Zaïre: Collaboration or competition?” Journal of Refugee Studies 9(3): 268-80.

Guha-Sapir, D. and W. Gijsbert (2004). "Conflict-related mortality: an analysis of 37 datasets," Disasters 28(4): 418-428.

Hacettepe University Institute of Population Studies (2019). 2018 Turkey Demographic and Health Survey. Ankara, Turkey.

Hargreaves, J.R., Collinson, M.A., Kahn, K., Clark, S.J. and S.M. Tollman (2004). "Childhood mortality among former Mozambican refugees and their host in rural South Africa." International Journal of Epidemiology 33(6), 1271-1278.

İçduygu, A. (2015). Syrian Refugees in Turkey: The Long Road Ahead, Migration Policy Institute, Washington, D.C.

Joint Assessment for Syrian Refugees in Egypt. (2013). Available from: https: //data.unher.org/syrianrefugees/download.php?id=6025.

Kalipeni, E. and J. Oppong (1998). "The refugee crisis in Africa and implications for health and disease: a political ecology approach," Social Science and Medicine 46(12):1637-53.

Kazmi, J.H. and K. Pandit (2001). "Disease and dislocation: the impact of refugee movements on the geography of malaria in NWFP, Pakistan," Social Science and Medicine 52(7):104355. 
Khawaja, M. (2004). "The extraordinary decline in infant and childhood mortality among Palestinian refugees," Social Science and Medicine 58(3): 463.

Kherallah, M., Alahfez, T., Sahloul, Z., Dia Eddin, K. and G. Jamil (2012). "Health care in Syria before and during the crisis," Avicenna Journal of Medicine 2(3): 51-53.

Leblebicioglu, H. (2016). "Managing health and infections in refugees: Turkey's experience," International Journal of Infectious Diseases 45S: 56.

Madi, H.H. (2000). "Infant and child mortality rates among Palestinian refugee populations," Lancet, 356(9226), 312.

Mardin F.D. (2017). “Access to Health Services for Syrian Refugees in Turkey,” MiReKoc Policy Brief Series 2017/01.

Maystadt J-F and G. Duranton (2019). "The development push of refugees: evidence from Tanzania,” Journal of Economic Geography 19(2): 299-334.

Maystadt J-F and P. Verwimp (2014). "Winners and losers among a refugee-hosting population," Economic Development and Cultural Change 62(4):769-809.

Maystadt, J-F., Hirvonen, K., Mabiso, A. \& Vandercasteelen J. (2019). Impacts of Hosting Forced Migrants in Poor Countries. Annual Review of Resource Economics 11: 439-59.

Minoiu, C. and O.N. Shemyakina (2014). "Armed conflict, household victimization, and child health in Cote d'Ivoire," Journal of Development Economics 108: 237-255.

Montalvo, J.G. and M. Reynal-Querol (2007). "Fighting against malaria: prevent wars while waiting for the 'miraculous' vaccine," Review of Economics and Statistics. 89(1):165-77.

Morales, J.S. (2018). "The impact of internal displacement on destination communities: evidence from the Colombian conflict," Journal of Development Economics 131: 132-50.

Orrenius, P.M. and M. Zavodny (2009). “Do immigrants work in riskier jobs?” Demography 46(3): $531-551$.

Orrenius, P.M. and M. Zavodny (2012). “Immigrants in risky occupations,” IZA Discussion Paper 6693.

Ozaras, R., Balkan, I.I. and M. Yemisen (2016a). "Prejudice and reality about infection risk among 
Syrian refugees," The Lancet Infectious Diseases 16(11): 1222-23.

Ozaras, R., Leblebicioglu, H., Sunbul, M., Tabak, F., Balkan, I.I., Yemisen, M., Sencan, I. and R. Ozturk (2016b). "The Syrian conflict and infectious diseases," Expert Review of AntiInfectious Therapy 14(6): 547-55.

Ozdagan H.K., Karateke, F., Ozdogan, M. and S. Satar (2014). "Syrian refugees in Turkey: Effects on intensive care," Lancet 384: 1427-1428.

Petersen, E., Baekeland, S., Memish, Z.A. and H. Leblebicioglu (2013). "Infectious disease risk from the Syrian conflict," International Journal of Infectious Diseases 17: e666-e667.

Porignon, D., Noterman, J.P., Hennart, P., Tonglet, R., Soron, G., et al. (1995). "The role of the Zairian health services in the Rwandan refugee crisis," Disasters 19(4):356-60.

Ruiz, I. and C. Vargas-Silva. (2016). "The labour market consequences of hosting refugees," Journal of Economic Geography 16(3): 667-94.

Ruiz, I. and C. Vargas-Silva. (2017). "The Consequences of forced migration for host communities in Africa," Revue d'économie du développement 25: 135-154.

Savas, N., Arslan, E., Inandi, T., Yeniceri, A., Erdem M., Kabacagoglu M., Peker, E. and O. Aliskin (2016). "Syrian refugees in Hatay/Turkey and their influence on health care at the university hospital,” International Journal of Clinical and Experimental Medicine 9(9): 18281-18290.

Singh, K., Karunakara, U., Burnham, G. and K. Hill. (2005a). "Using indirect methods to understand the impact of forced migration on long-term under-five mortality," Journal of Biosocial Science 37: 741-760.

Singh, K., Karunakara, U., Burnham, G. and K. Hill (2005b). "Forced migration and under-five mortality: a comparison of refugees and hosts in North-western Uganda and Southern Sudan," European Journal of Population 37: 741-760.

Turkish Disaster and Emergency Management Authority (TDEMA). (2013). Syrian refugees in Turkey, 2013: Field survey results. Ankara, Turkey.

Turkish Disaster and Emergency Management Authority (TDEMA) (2017). Population Influx from Syria to Turkey, Life in Turkey as a Syrian Guest. Retrieved from https://www.afad.gov.tr/kurumlar/afad.gov.tr/17933/xfiles/population_influx_1_.pdf. 
Turkish Directorate General for Migration Management (TDGMM). (2016). 2015 Türkiye Göç Raporu. Göç İdaresi Genel Müdürlügü Yayınları. Yayın No: 35.

Verwimp, P. and J. Van Bavel (2005). "Child survival and fertility of refugees in Rwanda," European Journal of Population 21(1): 271-290.

Whitaker B.E. (2002). "Refugees in WesternTanzania: the distribution of burdens and benefits among local hosts," Journal of Refugee Studies 15(4):339-58.

World Health Organization (2016). Health Status Survey of Syrian Refugees in Turkey.

World Health Organization (2019). Survey on the Health Status, Services Utilization and Determinants of Health of the Syrian Refugee Population in Turkey. WHO Regional Office for Europe: Copenhagen, Denmark. 


\section{Tables}

Table 1: Descriptive Statistics

Table 1: Descriptive Statistics

\begin{tabular}{|c|c|c|c|c|c|}
\hline & Mean & SD & Min. & Max. & No Obs. \\
\hline \multicolumn{6}{|l|}{ Mortality Rate (per 1000 births) } \\
\hline Day 0 & 1.634 & 0.876 & 0.000 & 5.742 & 648 \\
\hline Days 1-6 & 3.389 & 1.377 & 0.000 & 12.272 & 648 \\
\hline Week 1 & 5.023 & 1.926 & 0.000 & 14.025 & 648 \\
\hline Days 7-29 & 2.108 & 0.831 & 0.000 & 5.557 & 648 \\
\hline Days 1-29 & 5.497 & 1.878 & 0.471 & 16.830 & 648 \\
\hline Under Month 1 & 7.131 & 2.379 & 0.941 & 18.583 & 648 \\
\hline Months 1-11 & 3.887 & 1.589 & 0.000 & 9.149 & 648 \\
\hline Under Age 1 & 11.014 & 3.378 & 3.099 & 24.845 & 648 \\
\hline Under Age 5 & 13.682 & 4.520 & 4.132 & 31.782 & 648 \\
\hline \multicolumn{6}{|l|}{ Mortality Rate (per 1000 people) } \\
\hline $65+$ & 44.689 & 3.478 & 33.636 & 56.848 & 648 \\
\hline $75+$ & 78.328 & 6.652 & 55.935 & 97.663 & 648 \\
\hline All Ages & 5.807 & 1.595 & 2.659 & 10.146 & 648 \\
\hline \multicolumn{6}{|l|}{ Health Infrastructure (per 1000 people) } \\
\hline Doctors & 1.462 & 0.457 & 0.681 & 3.734 & 648 \\
\hline Nurses & 1.789 & 0.480 & 0.737 & 3.411 & 648 \\
\hline Midwives & 0.806 & 0.264 & 0.275 & 2.073 & 648 \\
\hline Hospital Beds & 2.559 & 0.882 & 0.831 & 6.537 & 648 \\
\hline Pediatricians & 0.036 & 0.009 & 0.004 & 0.071 & 324 \\
\hline Adult Intensive Care Beds & 0.128 & 0.049 & 0.040 & 0.337 & 324 \\
\hline Neonatal Intensive Care Beds & 0.048 & 0.020 & 0.009 & 0.114 & 324 \\
\hline \multicolumn{6}{|l|}{ Under-Age-1 Mortality Rate by Reason (per 1000 births) } \\
\hline Infectious Diseases* & 0.308 & 0.289 & 0.000 & 2.615 & 324 \\
\hline Certain infectious and parasitic diseases & 0.162 & 0.192 & 0.000 & 1.635 & 324 \\
\hline Endocrine, nutritional and metabolic diseases (includes malnutrition) & 0.128 & 0.170 & 0.000 & 1.105 & 324 \\
\hline Certain conditions originating in the perinatal period & 5.160 & 1.893 & 1.191 & 16.018 & 324 \\
\hline Symptoms, signs and abnormal clinical and laboratory findings & 0.420 & 0.434 & 0.000 & 3.184 & 324 \\
\hline Diseases of the respiratory system & 0.237 & 0.227 & 0.000 & 1.130 & 324 \\
\hline External causes of morbidity and mortality & 0.130 & 0.163 & 0.000 & 1.197 & 324 \\
\hline \multicolumn{6}{|l|}{ Socioeconomic Char acteristics } \\
\hline \multicolumn{6}{|l|}{ Ratio of women with } \\
\hline no degree & 0.216 & 0.111 & 0.072 & 0.652 & 648 \\
\hline primary or middle school degree & 0.528 & 0.069 & 0.271 & 0.665 & 648 \\
\hline high school degree & 0.166 & 0.041 & 0.055 & 0.261 & 648 \\
\hline university degree or higher & 0.090 & 0.038 & 0.018 & 0.242 & 648 \\
\hline Average household size & 3.886 & 1.087 & 2.700 & 8.400 & 648 \\
\hline Literacy rate & 0.942 & 0.032 & 0.804 & 0.988 & 648 \\
\hline Never married ratio (Female) & 0.237 & 0.060 & 0.155 & 0.425 & 648 \\
\hline Average first-marriage age (Female) & 23.268 & 1.103 & 21.000 & 28.200 & 648 \\
\hline GDP per capita (in 2009 Turkish Liras) & $18,942.160$ & $9,152.200$ & $4,210.000$ & $65,041.000$ & 648 \\
\hline
\end{tabular}

Notes: The data come from TurkStat and have panel structure for the 81 provinces in Turkey for the 2009-2017 period excluding 2012. The data on pediatricians and under -1 reasons of death are available only for years 2013-2016, and the data on adult and neonatal intensive care unit are available only for $2014-2017$. 
Table 2: Placebo Check for Health Infrastructure Outcomes - Regressions with Pre-Shock Data (2009-2011) where 2017 Values of the Endogenous and Instrumental Variables for each Province are assigned to 2011, 2SLS Estimates

\begin{tabular}{lccc}
\hline \multicolumn{4}{c}{ Dependent Variable: Health Input per capita (in Logarithmic Form) } \\
\hline Doctors & $(1)$ & $(2)$ & $(3)$ \\
& -0.237 & -0.188 & -0.239 \\
Nurses & $(0.155)$ & $(0.138)$ & $(0.146)$ \\
& -0.536 & -0.441 & -0.320 \\
Midwives & $(0.373)$ & $(0.382)$ & $(0.354)$ \\
& -0.021 & 0.054 & 0.016 \\
Hospital Beds & $(0.145)$ & $(0.153)$ & $(0.142)$ \\
& 0.131 & 0.004 & 0.051 \\
Hospitals & $(0.154)$ & $(0.145)$ & $(0.149)$ \\
& -0.118 & -0.169 & -0.110 \\
Controls for & $(0.167)$ & $(0.155)$ & $(0.153)$ \\
Year Fixed Effects & & & \\
Province Fixed Effects & Yes & Yes & Yes \\
5 Region Linear Time Trends & Yes & Yes & Yes \\
5 Region-Year Fixed Effects & No & Yes & No \\
\hline
\end{tabular}

Notes: Data come from TurkStat. The sample includes 81 provinces in the 2009-2011 period. In all regressions, there are 243 observations. As a placebo check, the ratios of refugees to natives across provinces for 2017 are assigned to 2011. Each cell shows the estimates for the key variable of interest -- the ratio of migrants to natives. 2SLS regression instruments the key variable of interest using a distance-based cross country instrument. The set of province-specific control variables included in the regressions are a set of geographical-area and calendaryear control variables as indicated above, the ratios of women with different levels of educational attainment (primary or secondary school, high school, and university or higher), the average household size, literacy rate, the fraction of women never-married, the average age of first-marriage for women, and the logarithm of GDP per capita. Regressions are weighted using province populations. Standard errors, given in parentheses, are clustered at the province level. *, **, or $* * *$ indicates significance at the $10 \%, 5 \%$ and $1 \%$ levels, respectively. 
Table 3: Placebo Check for Mortality Outcomes - Regressions with Pre-Shock Data (2009-2011) where 2017 Values of the Endogenous and Instrumental Variables for each Province are assigned to 2011, 2SLS Estimates

\begin{tabular}{|c|c|c|c|}
\hline \multicolumn{4}{|c|}{ Dependent Variable: Mortality Rate (in Logarithmic Form) } \\
\hline Period for Mortality Outcome & $(1)$ & $(2)$ & $(3)$ \\
\hline All Ages & $\begin{array}{c}-0.213 \\
(0.149)\end{array}$ & $\begin{array}{c}-0.228 \\
(0.154)\end{array}$ & $\begin{array}{l}-0.246 \\
(0.171)\end{array}$ \\
\hline Under Age 1 & $\begin{array}{c}0.177 \\
(0.462)\end{array}$ & $\begin{array}{c}0.165 \\
(0.320)\end{array}$ & $\begin{array}{c}0.103 \\
(0.351)\end{array}$ \\
\hline Under Age 5 & $\begin{array}{c}0.223 \\
(0.381)\end{array}$ & $\begin{array}{c}0.177 \\
(0.275)\end{array}$ & $\begin{array}{c}0.132 \\
(0.295)\end{array}$ \\
\hline Ages $65+$ & $\begin{array}{c}-0.220 * \\
(0.122)\end{array}$ & $\begin{array}{c}-0.186 \\
(0.138)\end{array}$ & $\begin{array}{l}-0.203 \\
(0.153)\end{array}$ \\
\hline Ages $75+$ & $\begin{array}{c}-0.246 \\
(0.177)\end{array}$ & $\begin{array}{c}-0.243 \\
(0.194)\end{array}$ & $\begin{array}{l}-0.282 \\
(0.206)\end{array}$ \\
\hline Day 0 & $\begin{array}{c}-0.274 \\
(1.143)\end{array}$ & $\begin{array}{c}-0.018 \\
(0.924)\end{array}$ & $\begin{array}{l}-0.241 \\
(0.910)\end{array}$ \\
\hline Days 1-6 & $\begin{array}{c}0.446 \\
(0.767)\end{array}$ & $\begin{array}{c}0.762 \\
(0.543)\end{array}$ & $\begin{array}{c}0.645 \\
(0.550)\end{array}$ \\
\hline Week 1 & $\begin{array}{c}0.317 \\
(0.807)\end{array}$ & $\begin{array}{c}0.642 \\
(0.577)\end{array}$ & $\begin{array}{c}0.508 \\
(0.576)\end{array}$ \\
\hline Days 7-29 & $\begin{array}{c}1.035^{*} \\
(0.620)\end{array}$ & $\begin{array}{c}0.742 \\
(0.528)\end{array}$ & $\begin{array}{c}0.711 \\
(0.561)\end{array}$ \\
\hline Days 1-29 & $\begin{array}{c}0.567 \\
(0.627)\end{array}$ & $\begin{array}{c}0.685 \\
(0.452)\end{array}$ & $\begin{array}{c}0.583 \\
(0.469)\end{array}$ \\
\hline Under Month 1 & $\begin{array}{c}0.444 \\
(0.673)\end{array}$ & $\begin{array}{c}0.606 \\
(0.489)\end{array}$ & $\begin{array}{c}0.501 \\
(0.504)\end{array}$ \\
\hline Months 1-11 & $\begin{array}{c}-0.207 \\
(0.343) \\
\end{array}$ & $\begin{array}{c}-0.498 \\
(0.379) \\
\end{array}$ & $\begin{array}{l}-0.449 \\
(0.412) \\
\end{array}$ \\
\hline \multicolumn{4}{|l|}{ Controls for } \\
\hline Year Fixed Effects & Yes & $\begin{array}{l}\text { Yes } \\
\text { Yes }\end{array}$ & Yes \\
\hline $\begin{array}{l}\text { Province Fixed Effects } \\
5 \text { Region Linear Time Trends }\end{array}$ & $\begin{array}{l}\text { Yes } \\
\text { No }\end{array}$ & $\begin{array}{l}\text { Yes } \\
\text { Yes }\end{array}$ & $\begin{array}{l}\text { Yes } \\
\text { No }\end{array}$ \\
\hline 5 Region-Year Fixed Effects & No & No & Yes \\
\hline
\end{tabular}

Notes: Data come from TurkStat. The sample includes 81 provinces in the 2009-2011 period. In all regressions, there are 243 observations. As a placebo check, the ratios of refugees to natives across provinces for 2017 are assigned to 2011. Each cell shows the estimates for the key variable of interest -- the ratio of migrants to natives. 2SLS regression instruments the key variable of interest using a distance-based cross country instrument. The set of province-specific control variables included in the regressions are a set of geographical-area and calendar-year control variables as indicated above, the ratios of women with different levels of educational attainment (primary or secondary school, high school, and university or higher), the average household size, literacy rate, the fraction of women never-married, the average age of first-marriage for women, and the logarithm of GDP per capita. Regressions are weighted using number of births by province for all infant and child mortality outcomes and agespecific province populations in other mortality outcomes. Standard errors, given in parentheses, are clustered at the province level. *,**, or $* * *$ indicates significance at the $10 \%, 5 \%$ and $1 \%$ levels, respectively. 
Table 4: Investment in Health Sector Infrastructure in Refugee-Hosting Regions

\begin{tabular}{|c|c|c|c|c|c|c|}
\hline \multirow{2}{*}{$\begin{array}{l}\text { Dependent Variable } \\
\text { (in logarithmic form) }\end{array}$} & $(1)$ & (2) & (3) & (4) & $(5)$ & (6) \\
\hline & \multicolumn{3}{|c|}{ OLS } & \multicolumn{3}{|c|}{ 2SLS } \\
\hline \multicolumn{7}{|c|}{ PANEL A - Data time period: 2009-17 } \\
\hline Doctors & $\begin{array}{c}0.130 \\
(0.143)\end{array}$ & $\begin{array}{c}0.101 \\
(0.169)\end{array}$ & $\begin{array}{c}0.153 \\
(0.149)\end{array}$ & $\begin{array}{c}0.025 \\
(0.229)\end{array}$ & $\begin{array}{c}0.036 \\
(0.279)\end{array}$ & $\begin{array}{c}0.116 \\
(0.267)\end{array}$ \\
\hline Nurses & $\begin{array}{c}0.665^{* * *} \\
(0.198)\end{array}$ & $\begin{array}{c}0.671^{* * *} \\
(0.185)\end{array}$ & $\begin{array}{c}0.667 * * * \\
(0.200)\end{array}$ & $\begin{array}{c}0.702 * * \\
(0.314)\end{array}$ & $\begin{array}{c}0.800 * * * \\
(0.239)\end{array}$ & $\begin{array}{c}0.785^{* * *} \\
(0.267)\end{array}$ \\
\hline Midwives & $\begin{array}{c}0.412 * * \\
(0.184)\end{array}$ & $\begin{array}{c}0.388 * * \\
(0.192)\end{array}$ & $\begin{array}{c}0.298 \\
(0.182)\end{array}$ & $\begin{array}{c}0.330 \\
(0.279)\end{array}$ & $\begin{array}{c}0.233 \\
(0.280)\end{array}$ & $\begin{array}{c}0.059 \\
(0.287)\end{array}$ \\
\hline Hospital Beds & $\begin{array}{c}0.729 * * * \\
(0.221)\end{array}$ & $\begin{array}{c}0.706^{* * *} \\
(0.196)\end{array}$ & $\begin{array}{c}0.701 * * * \\
(0.207)\end{array}$ & $\begin{array}{c}0.778 * * \\
(0.353)\end{array}$ & $\begin{array}{c}0.762 * * * \\
(0.273)\end{array}$ & $\begin{array}{c}0.826^{* * * *} \\
(0.276)\end{array}$ \\
\hline Hospitals & $\begin{array}{c}0.396 * * \\
(0.164) \\
\end{array}$ & $\begin{array}{c}0.359 * * \\
(0.150) \\
\end{array}$ & $\begin{array}{c}0.342 * * \\
(0.168) \\
\end{array}$ & $\begin{array}{c}0.487 \\
(0.348) \\
\end{array}$ & $\begin{array}{r}0.396 \\
(0.248) \\
\end{array}$ & $\begin{array}{r}0.367 \\
(0.265) \\
\end{array}$ \\
\hline First-stage regression & & & & $\begin{array}{c}2.508 * * * \\
(0.453)\end{array}$ & $\begin{array}{c}2.761 * * * \\
(0.570)\end{array}$ & $\begin{array}{c}2.773 * * * \\
(0.629)\end{array}$ \\
\hline F-statistics & & & & 30.409 & 23.360 & 19.773 \\
\hline \multicolumn{7}{|c|}{ PANEL B - Data time period: 2013-16 } \\
\hline Pediatricians & $\begin{array}{c}1.769 * * * \\
(0.608) \\
\end{array}$ & $\begin{array}{c}1.767 * * * \\
(0.646) \\
\end{array}$ & $\begin{array}{c}1.758 * * * \\
(0.612) \\
\end{array}$ & $\begin{array}{c}1.650 * * * \\
(0.546) \\
\end{array}$ & $\begin{array}{c}1.778 * * * \\
(0.616) \\
\end{array}$ & $\begin{array}{c}2.020 * * * \\
(0.700) \\
\end{array}$ \\
\hline First-stage regression & & & & $\begin{array}{c}2.812 * * * \\
(0.610)\end{array}$ & $\begin{array}{c}3.091 * * * \\
(0.767)\end{array}$ & $\begin{array}{c}3.156^{* * *} \\
(0.838)\end{array}$ \\
\hline F-statistics & & & & 21.643 & 16.587 & 16.667 \\
\hline \multicolumn{7}{|c|}{ PANEL C - Data time period: 2014-17 } \\
\hline Adult Intensive Care Bed & $\begin{array}{c}0.486 \\
(0.388)\end{array}$ & $\begin{array}{l}-0.004 \\
(0.532)\end{array}$ & $\begin{array}{c}0.046 \\
(0.522)\end{array}$ & $\begin{array}{c}0.710 \\
(0.688)\end{array}$ & $\begin{array}{l}-0.234 \\
(0.733)\end{array}$ & $\begin{array}{l}-0.103 \\
(0.724)\end{array}$ \\
\hline Neonatal Intensive Care Bed & $\begin{array}{r}1.115 \\
(0.783) \\
\end{array}$ & $\begin{array}{c}0.792 \\
(0.849) \\
\end{array}$ & $\begin{array}{r}1.081 \\
(0.812) \\
\end{array}$ & $\begin{array}{c}1.151 \\
(1.045) \\
\end{array}$ & $\begin{array}{c}0.103 \\
(0.917) \\
\end{array}$ & $\begin{array}{c}0.548 \\
(0.920) \\
\end{array}$ \\
\hline First-stage regression & & & & $\begin{array}{c}3.833 * * * \\
(0.777)\end{array}$ & $\begin{array}{c}4.206^{* * * *} \\
(0.924)\end{array}$ & $\begin{array}{c}4.191^{* * *} \\
(1.031)\end{array}$ \\
\hline F-statistics & & & & 24.761 & 21.203 & 19.400 \\
\hline \multicolumn{7}{|l|}{ Controls for } \\
\hline Year Fixed Effects & Yes & Yes & Yes & Yes & Yes & Yes \\
\hline Province Fixed Effects & Yes & Yes & Yes & Yes & Yes & Yes \\
\hline 5 Region Linear Time Trends & No & Yes & No & No & Yes & No \\
\hline 5 Region-Year Fixed Effects & No & No & Yes & No & No & Yes \\
\hline
\end{tabular}

Notes: Information on the health infrastructure variables is obtained from TurkStat. The full sample is for the 2009-17 period, excluding 2012, at the 81province level. The number of observations is 648 in panel (A), whereas it is 324 in panel (B) and panel (C) as the variables in these panels are available for recent years only. Each cell shows the estimates for the ratio of migrants to natives. The 2SLS regression instruments the key variable of interest using a distance-based cross-country instrument. The set of province-specific control variables included in the regressions are a set of geographical-area and year specific control variables as indicated above, the ratios of women with different levels of educational attainment (primary or secondary school, high school, and university or higher), the average household size, literacy rate, the fraction of women never-married, the average age of first-marriage for women, the logarithm of GDP per capita, and the logarithm of the province population. Regressions are weighted using province populations. Standard errors, given in parentheses, are clustered at the province level. *, **, or *** indicates significance at the $10 \%, 5 \%$ and $1 \%$ levels, respectively. 
Table 5: Effect of Refugees on the Health Sector Infrastructure

\begin{tabular}{|c|c|c|c|c|c|c|}
\hline \multirow{2}{*}{$\begin{array}{l}\text { Dependent Variable (per capita) } \\
\text { (in logarithmic form) }\end{array}$} & $(1)$ & $(2)$ & (3) & (4) & $(5)$ & (6) \\
\hline & \multicolumn{3}{|c|}{ OLS } & \multicolumn{3}{|c|}{ 2SLS } \\
\hline \multicolumn{7}{|c|}{ PANEL A - Data time period: 2009-17 } \\
\hline Doctors & $\begin{array}{c}-0.747 * * * \\
(0.209)\end{array}$ & $\begin{array}{c}-0.782 * * * \\
(0.241)\end{array}$ & $\begin{array}{c}-0.729 * * * \\
(0.222)\end{array}$ & $\begin{array}{c}-0.911 * * * \\
(0.280)\end{array}$ & $\begin{array}{c}-0.932 * * * \\
(0.318)\end{array}$ & $\begin{array}{c}-0.857 * * * \\
(0.306)\end{array}$ \\
\hline Nurses & $\begin{array}{l}-0.278^{*} \\
(0.166)\end{array}$ & $\begin{array}{c}-0.295^{* *} \\
(0.140)\end{array}$ & $\begin{array}{c}-0.303^{* *} \\
(0.139)\end{array}$ & $\begin{array}{l}-0.311 \\
(0.393)\end{array}$ & $\begin{array}{l}-0.296 \\
(0.302)\end{array}$ & $\begin{array}{l}-0.324 \\
(0.299)\end{array}$ \\
\hline Midwives & $\begin{array}{c}-0.540 * * * \\
(0.182)\end{array}$ & $\begin{array}{c}-0.580 * * * \\
(0.203)\end{array}$ & $\begin{array}{c}-0.664 * * * \\
(0.225)\end{array}$ & $\begin{array}{c}-0.691 * * * \\
(0.256)\end{array}$ & $\begin{array}{c}-0.854 * * * \\
(0.244)\end{array}$ & $\begin{array}{c}-1.020 * * * \\
(0.288)\end{array}$ \\
\hline Hospital Beds & $\begin{array}{l}-0.082 \\
(0.177)\end{array}$ & $\begin{array}{l}-0.102 \\
(0.149)\end{array}$ & $\begin{array}{l}-0.103 \\
(0.159)\end{array}$ & $\begin{array}{l}-0.089 \\
(0.336)\end{array}$ & $\begin{array}{l}-0.106 \\
(0.257)\end{array}$ & $\begin{array}{l}-0.043 \\
(0.258)\end{array}$ \\
\hline Hospitals & $\begin{array}{c}-0.471^{* *} \\
(0.215) \\
\end{array}$ & $\begin{array}{c}-0.502 * * \\
(0.220) \\
\end{array}$ & $\begin{array}{c}-0.524 * * \\
(0.247) \\
\end{array}$ & $\begin{array}{r}-0.443 \\
(0.305) \\
\end{array}$ & $\begin{array}{c}-0.547 * * \\
(0.224) \\
\end{array}$ & $\begin{array}{c}-0.586^{* *} \\
(0.242) \\
\end{array}$ \\
\hline First-stage regression & & & & $\begin{array}{c}2.536 * * * \\
(0.445)\end{array}$ & $\begin{array}{c}2.795 * * * \\
(0.562)\end{array}$ & $\begin{array}{c}2.816^{* * * *} \\
(0.617)\end{array}$ \\
\hline F-statistics & & & & 32.184 & 24.588 & 21.154 \\
\hline \multicolumn{7}{|c|}{ PANEL B - Data time period: 2013-16 } \\
\hline Pediatricians & $\begin{array}{l}0.833^{*} \\
(0.450) \\
\end{array}$ & $\begin{array}{l}0.798^{*} \\
(0.449) \\
\end{array}$ & $\begin{array}{l}0.785^{*} \\
(0.410) \\
\end{array}$ & $\begin{array}{r}0.624 \\
(0.526) \\
\end{array}$ & $\begin{array}{c}0.644 \\
(0.524) \\
\end{array}$ & $\begin{array}{r}0.889 \\
(0.548) \\
\end{array}$ \\
\hline First-stage regression & & & & $\begin{array}{c}2.842 * * * \\
(0.595)\end{array}$ & $\begin{array}{c}3.131 * * * \\
(0.745)\end{array}$ & $\begin{array}{c}3.202 * * * \\
(0.812)\end{array}$ \\
\hline F-statistics & & & & 23.189 & 18.082 & 18.238 \\
\hline \multicolumn{7}{|c|}{ PANEL C - Data time period: $2014-17$} \\
\hline Adult Intensive Care Beds & $\begin{array}{l}-0.379 \\
(0.421)\end{array}$ & $\begin{array}{l}-0.862 \\
(0.575)\end{array}$ & $\begin{array}{l}-0.818 \\
(0.573)\end{array}$ & $\begin{array}{l}-0.195 \\
(0.629)\end{array}$ & $\begin{array}{l}-1.146^{*} \\
(0.681)\end{array}$ & $\begin{array}{l}-1.035 \\
(0.673)\end{array}$ \\
\hline Neonatal Intensive Care Beds & $\begin{array}{c}0.434 \\
(0.814)\end{array}$ & $\begin{array}{c}0.162 \\
(0.858)\end{array}$ & $\begin{array}{c}0.402 \\
(0.823)\end{array}$ & $\begin{array}{c}0.408 \\
(1.068)\end{array}$ & $\begin{array}{l}-0.496 \\
(0.955)\end{array}$ & $\begin{array}{l}-0.119 \\
(0.928)\end{array}$ \\
\hline First-stage regression & & & & $\begin{array}{c}3.914 * * * \\
(0.765)\end{array}$ & $\begin{array}{c}4.323 * * * \\
(0.926)\end{array}$ & $\begin{array}{c}4.309 * * * \\
(1.026)\end{array}$ \\
\hline F-statistics & & & & 26.607 & 22.278 & 20.700 \\
\hline \multicolumn{7}{|l|}{ Controls for } \\
\hline Year Fixed Effects & Yes & Yes & Yes & Yes & Yes & Yes \\
\hline Province Fixed Effects & Yes & Yes & Yes & Yes & Yes & Yes \\
\hline 5 Region Linear Time Trends & No & Yes & No & No & Yes & No \\
\hline 5 Region-Year Fixed Effects & No & No & Yes & No & No & Yes \\
\hline
\end{tabular}

Notes: Information on the health infrastructure variables is obtained from TurkStat. The full sample is for the 2009-17 period, excluding 2012, at the 81-province level. The number of observations is 648 in panel (A), whereas it is 324 in panel (B) and (C) as the variables in these panels are available for recent years only. Each cell shows the estimates for the ratio of migrants to natives. The 2SLS regression instruments the key variable of interest using a distance-based cross-country instrument. The set of province-specific control variables included in the regressions are a set of geographical-area and year specific control variables as indicated above, the ratios of women with different levels of educational attainment (primary or secondary school, high school, and university or higher), the average household size, literacy rate, the fraction of women never-married, the average age of first-marriage for women, and the logarithm of GDP per capita. Regressions are weighted using province populations. Standard errors, given in parentheses, are clustered at the province level. *,**, or *** indicates significance at the $10 \%$, $5 \%$ and $1 \%$ levels, respectively. 
Table 6: Effect of Refugees on Native Mortality by Age Group

\begin{tabular}{|c|c|c|c|c|c|c|}
\hline \multicolumn{7}{|c|}{ Dependent Variable: Mortality Rate (in logarithmic form) } \\
\hline \multirow[b]{2}{*}{ Age Period } & $(1)$ & $(2)$ & (3) & (4) & $(5)$ & (6) \\
\hline & \multicolumn{3}{|c|}{ OLS } & \multicolumn{3}{|c|}{ 2SLS } \\
\hline Under Age 1 & $\begin{array}{c}0.153 \\
(0.165)\end{array}$ & $\begin{array}{c}0.129 \\
(0.194)\end{array}$ & $\begin{array}{c}0.327 \\
(0.207)\end{array}$ & $\begin{array}{l}-0.252 \\
(0.403)\end{array}$ & $\begin{array}{l}-0.495 \\
(0.425)\end{array}$ & $\begin{array}{l}-0.113 \\
(0.409)\end{array}$ \\
\hline Under Age 5 & $\begin{array}{r}0.207 \\
(0.137) \\
\end{array}$ & $\begin{array}{c}0.150 \\
(0.152) \\
\end{array}$ & $\begin{array}{l}0.321^{*} \\
(0.162) \\
\end{array}$ & $\begin{array}{c}0.083 \\
(0.299) \\
\end{array}$ & $\begin{array}{r}-0.175 \\
(0.318) \\
\end{array}$ & $\begin{array}{c}0.177 \\
(0.302) \\
\end{array}$ \\
\hline First-stage regression & & & & $\begin{array}{c}2.563 * * * \\
(0.491)\end{array}$ & $\begin{array}{c}2.850^{* * *} \\
(0.606)\end{array}$ & $\begin{array}{c}2.883 * * * \\
(0.666)\end{array}$ \\
\hline F-statistics & & & & 27.040 & 21.997 & 19.057 \\
\hline Ages: $65+$ & $\begin{array}{c}0.012 \\
(0.045) \\
\end{array}$ & $\begin{array}{l}-0.020 \\
(0.042) \\
\end{array}$ & $\begin{array}{l}-0.031 \\
(0.041) \\
\end{array}$ & $\begin{array}{c}0.088 \\
(0.069) \\
\end{array}$ & $\begin{array}{c}0.047 \\
(0.060) \\
\end{array}$ & $\begin{array}{c}0.043 \\
(0.062) \\
\end{array}$ \\
\hline First-stage regression & & & & $\begin{array}{c}2.662 * * * \\
(0.513)\end{array}$ & $\begin{array}{c}2.922 * * * \\
(0.671)\end{array}$ & $\begin{array}{c}2.940 * * * \\
(0.730)\end{array}$ \\
\hline F-statistics & & & & 26.714 & 18.877 & 16.507 \\
\hline Ages: $75+$ & $\begin{array}{l}-0.031 \\
(0.116) \\
\end{array}$ & $\begin{array}{l}-0.079 \\
(0.097) \\
\end{array}$ & $\begin{array}{l}-0.090 \\
(0.097) \\
\end{array}$ & $\begin{array}{c}0.117 \\
(0.139) \\
\end{array}$ & $\begin{array}{c}0.040 \\
(0.151) \\
\end{array}$ & $\begin{array}{c}0.036 \\
(0.155) \\
\end{array}$ \\
\hline First-stage regression & & & & $\begin{array}{c}2.705 * * * \\
(0.554)\end{array}$ & $\begin{array}{c}2.976^{* * *} \\
(0.724)\end{array}$ & $\begin{array}{c}2.999 * * * \\
(0.787)\end{array}$ \\
\hline$\underline{\text { F-statistics }}$ & & & & 23.694 & 16.827 & 14.748 \\
\hline All Ages & $\begin{array}{c}0.026 \\
(0.061)\end{array}$ & $\begin{array}{l}-0.056 \\
(0.054)\end{array}$ & $\begin{array}{l}-0.049 \\
(0.054)\end{array}$ & $\begin{array}{l}0.164 * \\
(0.087)\end{array}$ & $\begin{array}{l}-0.031 \\
(0.072)\end{array}$ & $\begin{array}{l}-0.002 \\
(0.077)\end{array}$ \\
\hline First-stage regression & & & & $\begin{array}{c}2.536^{* * *} \\
(0.445)\end{array}$ & $\begin{array}{c}2.795 * * * \\
(0.562)\end{array}$ & $\begin{array}{c}2.816^{* * *} \\
(0.617)\end{array}$ \\
\hline F-statistics & & & & 32.184 & 24.588 & 21.154 \\
\hline Controls for & & & & & & \\
\hline Year Fixed Effects & Yes & Yes & Yes & Yes & Yes & Yes \\
\hline Province Fixed Effects & Yes & Yes & Yes & Yes & Yes & Yes \\
\hline 5 Region Linear Time Trends & No & Yes & No & No & Yes & No \\
\hline 5 Region-Year Fixed Effects & No & No & Yes & No & No & Yes \\
\hline
\end{tabular}

Notes: Data come from TurkStat. The sample includes 81 provinces in the 2009-2017 period excluding year 2012. The number of observations is 648 . Each cell comes from a separate regression and shows the estimates for the ratio of migrants to natives. The 2SLS regression instruments the key variable of interest using a distance-based cross-country instrument. The set of province-specific control variables included in the regressions are a set of geographical-area and year specific control variables as indicated above, the ratios of women with different levels of educational attainment (primary or secondary school, high school, and university or higher), the average household size, literacy rate, the fraction of women never-married, the average age of first-marriage for women, and the logarithm of GDP per capita. Regressions are weighted using the number of births by province in infant and child mortality regressions and using the populations of age groups by province in mortality regressions by age. Standard errors, given in parentheses, are clustered at the province level. *, **, or *** indicates significance at the $10 \%, 5 \%$ and $1 \%$ levels, respectively. 
Table 7: Effect of Refugees on Infant Mortality among Natives

\begin{tabular}{|c|c|c|c|c|c|c|}
\hline \multicolumn{7}{|c|}{ Dependent Variable: Mortality in a Given Period (in logarithmic form) } \\
\hline \multirow[b]{2}{*}{ Day/Month Period } & $(1)$ & (2) & $(3)$ & $(4)$ & $(5)$ & $(6)$ \\
\hline & \multicolumn{3}{|c|}{ OLS } & \multicolumn{3}{|c|}{ 2SLS } \\
\hline Day 0 & $\begin{array}{l}-0.237 \\
(0.641)\end{array}$ & $\begin{array}{l}-0.281 \\
(0.631)\end{array}$ & $\begin{array}{l}-0.017 \\
(0.639)\end{array}$ & $\begin{array}{c}-0.746 \\
(1.498)\end{array}$ & $\begin{array}{l}-1.248 \\
(1.600)\end{array}$ & $\begin{array}{l}-0.654 \\
(1.557)\end{array}$ \\
\hline Days 1-6 & $\begin{array}{c}0.316 \\
(0.333)\end{array}$ & $\begin{array}{c}0.218 \\
(0.363)\end{array}$ & $\begin{array}{c}0.353 \\
(0.388)\end{array}$ & $\begin{array}{l}-0.240 \\
(0.591)\end{array}$ & $\begin{array}{l}-0.583 \\
(0.571)\end{array}$ & $\begin{array}{c}-0.331 \\
(0.662)\end{array}$ \\
\hline Week 1 & $\begin{array}{c}0.166 \\
(0.352)\end{array}$ & $\begin{array}{c}0.063 \\
(0.362)\end{array}$ & $\begin{array}{c}0.229 \\
(0.395)\end{array}$ & $\begin{array}{l}-0.311 \\
(0.747)\end{array}$ & $\begin{array}{l}-0.729 \\
(0.778)\end{array}$ & $\begin{array}{l}-0.378 \\
(0.830)\end{array}$ \\
\hline Days 7-29 & $\begin{array}{l}-0.035 \\
(0.300)\end{array}$ & $\begin{array}{c}0.098 \\
(0.339)\end{array}$ & $\begin{array}{l}0.523^{*} \\
(0.266)\end{array}$ & $\begin{array}{c}-0.736 \\
(0.608)\end{array}$ & $\begin{array}{l}-0.761 \\
(0.636)\end{array}$ & $\begin{array}{l}-0.040 \\
(0.489)\end{array}$ \\
\hline Days 1-29 & $\begin{array}{c}0.210 \\
(0.245)\end{array}$ & $\begin{array}{c}0.190 \\
(0.290)\end{array}$ & $\begin{array}{c}0.416 \\
(0.309)\end{array}$ & $\begin{array}{c}-0.378 \\
(0.527)\end{array}$ & $\begin{array}{l}-0.619 \\
(0.532)\end{array}$ & $\begin{array}{c}-0.236 \\
(0.547)\end{array}$ \\
\hline Under Month 1 & $\begin{array}{c}0.151 \\
(0.282)\end{array}$ & $\begin{array}{c}0.108 \\
(0.307)\end{array}$ & $\begin{array}{c}0.339 \\
(0.327)\end{array}$ & $\begin{array}{l}-0.363 \\
(0.653)\end{array}$ & $\begin{array}{l}-0.681 \\
(0.686)\end{array}$ & $\begin{array}{l}-0.254 \\
(0.686)\end{array}$ \\
\hline Month 1-11 & $\begin{array}{c}0.027 \\
(0.117) \\
\end{array}$ & $\begin{array}{c}0.054 \\
(0.141) \\
\end{array}$ & $\begin{array}{c}0.202 \\
(0.168) \\
\end{array}$ & $\begin{array}{c}-0.294 \\
(0.226)\end{array}$ & $\begin{array}{l}-0.347 \\
(0.253)\end{array}$ & $\begin{array}{l}-0.026 \\
(0.245)\end{array}$ \\
\hline First-stage regression & & & & $\begin{array}{c}2.563 * * * \\
(0.491)\end{array}$ & $\begin{array}{c}2.850 * * * \\
(0.606)\end{array}$ & $\begin{array}{c}2.883 * * * \\
(0.666)\end{array}$ \\
\hline F-statistics & & & & 27.040 & 21.997 & 19.057 \\
\hline Controls for & & & & & & \\
\hline Year Fixed Effects & Yes & Yes & Yes & Yes & Yes & Yes \\
\hline Province Fixed Effects & Yes & Yes & Yes & Yes & Yes & Yes \\
\hline 5 Region Linear Time Trends & No & Yes & No & No & Yes & No \\
\hline 5 Region-Year Fixed Effects & No & No & Yes & No & No & Yes \\
\hline
\end{tabular}

Notes: Data come from TurkStat. The sample includes 81 provinces in the 2009-2017 period excluding year 2012. The number of observations is 648 . Each cell comes from a separate regression and shows the estimates for the ratio of migrants to natives. The 2SLS regression instruments the key variable of interest using a distance-based cross-country instrument. The set of province-specific control variables included in the regressions are a set of geographical-area and year specific control variables as indicated above, the ratios of women with different levels of educational attainment (primary or secondary school, high school, and university or higher), the average household size, literacy rate, the fraction of women never-married, the average age of first-marriage for women, and the logarithm of GDP per capita. Regressions are weighted using province populations. Standard errors, given in parentheses, are clustered at the province level. *, **, or *** indicates significance at the $10 \%, 5 \%$ and $1 \%$ levels, respectively. 
Table 8: Effect of Refugees on Native Infant Mortality by Reasons of Death

\begin{tabular}{|c|c|c|c|}
\hline \multirow[b]{2}{*}{ Dependent Variable: Mortality by Reason (in logarithmic form) } & $(1)$ & $(2)$ & $(3)$ \\
\hline & \multicolumn{3}{|c|}{ OLS } \\
\hline $\begin{array}{l}\text { Under } 1 \text { - Infectious Diseases } \\
\text { ICD-10: A00-A999, B00-B999, J00-J029, J10-J118, J20-J229, LOO-LO89. }\end{array}$ & $\begin{array}{l}-0.428 \\
(1.539)\end{array}$ & $\begin{array}{c}0.065 \\
(1.745)\end{array}$ & $\begin{array}{c}0.033 \\
(1.757)\end{array}$ \\
\hline $\begin{array}{l}\text { Under } 1 \text { - Reason A \& B } \\
\text { Certain infectious and par asitic diseases }\end{array}$ & $\begin{array}{l}-1.899 \\
(1.710)\end{array}$ & $\begin{array}{l}-1.339 \\
(1.805)\end{array}$ & $\begin{array}{l}-1.317 \\
(1.821)\end{array}$ \\
\hline $\begin{array}{l}\text { Under } 1 \text { - Reason E } \\
\text { Endocrine, nutritional and metabolic diseases (includes malnutrition) }\end{array}$ & $\begin{array}{l}-1.523 \\
(1.897)\end{array}$ & $\begin{array}{c}0.060 \\
(1.968)\end{array}$ & $\begin{array}{c}0.171 \\
(2.092)\end{array}$ \\
\hline $\begin{array}{l}\text { Under } 1 \text { - Reason J } \\
\text { Diseases of the respiratory system }\end{array}$ & $\begin{array}{l}-0.613 \\
(1.885)\end{array}$ & $\begin{array}{l}-0.216 \\
(1.797)\end{array}$ & $\begin{array}{l}-0.312 \\
(1.687)\end{array}$ \\
\hline $\begin{array}{l}\text { Under } 1 \text { - Reason } \mathrm{P} \\
\text { Certain conditions originating in the perinatal period }\end{array}$ & $\begin{array}{l}-0.464 \\
(0.375)\end{array}$ & $\begin{array}{l}-0.401 \\
(0.378)\end{array}$ & $\begin{array}{l}-0.461 \\
(0.371)\end{array}$ \\
\hline $\begin{array}{l}\text { Under } 1 \text { - Reason R } \\
\text { Symptoms, signs and abnormal clinical and labor atory findings, not elsewhere classified }\end{array}$ & $\begin{array}{l}-1.156 \\
(1.372)\end{array}$ & $\begin{array}{l}-1.058 \\
(1.568)\end{array}$ & $\begin{array}{l}-1.078 \\
(1.619)\end{array}$ \\
\hline \multirow[t]{2}{*}{ External causes of morbidity and mortality } & $\begin{array}{l}-0.676 \\
(3.100)\end{array}$ & $\begin{array}{l}-1.088 \\
(2.735) \\
\end{array}$ & $\begin{array}{l}-1.176 \\
(2.641) \\
\end{array}$ \\
\hline & \multicolumn{3}{|c|}{ 2SLS } \\
\hline $\begin{array}{l}\text { Under } 1 \text { - Infectious Diseases } \\
\text { ICD-10: A00-A999, B00-B999, J00-J029, J10-J118, J20-J229, LOO-L089. }\end{array}$ & $\begin{array}{l}-1.856 \\
(3.609)\end{array}$ & $\begin{array}{l}-0.737 \\
(3.790)\end{array}$ & $\begin{array}{l}-0.469 \\
(3.679)\end{array}$ \\
\hline $\begin{array}{l}\text { Under } 1 \text { - Reason A \& B } \\
\text { Certain infectious and par asitic diseases }\end{array}$ & $\begin{array}{l}-3.456 \\
(3.178)\end{array}$ & $\begin{array}{l}-1.321 \\
(3.093)\end{array}$ & $\begin{array}{l}-1.063 \\
(2.991)\end{array}$ \\
\hline $\begin{array}{l}\text { Under } 1 \text { - Reason E } \\
\text { Endocrine, nutritional and metabolic diseases (includes malnutrition) }\end{array}$ & $\begin{array}{l}-4.774 * \\
(2.850)\end{array}$ & $\begin{array}{c}0.094 \\
(3.908)\end{array}$ & $\begin{array}{l}-0.149 \\
(3.571)\end{array}$ \\
\hline $\begin{array}{l}\text { Under } 1 \text { - Reason J } \\
\text { Diseases of the respiratory system }\end{array}$ & $\begin{array}{l}-4.229 \\
(5.688)\end{array}$ & $\begin{array}{l}-3.175 \\
(4.779)\end{array}$ & $\begin{array}{l}-2.348 \\
(4.534)\end{array}$ \\
\hline $\begin{array}{l}\text { Under } 1 \text { - Reason } \mathrm{P} \\
\text { Certain conditions originating in the perinatal period }\end{array}$ & $\begin{array}{l}-0.564 \\
(0.668)\end{array}$ & $\begin{array}{l}-0.211 \\
(0.588)\end{array}$ & $\begin{array}{l}-0.337 \\
(0.602)\end{array}$ \\
\hline $\begin{array}{l}\text { Under } 1 \text { - Reason R } \\
\text { Symptoms, signs and abnormal clinical and labor atory findings, not elsewhere classified }\end{array}$ & $\begin{array}{l}-2.395 \\
(1.929)\end{array}$ & $\begin{array}{l}-1.180 \\
(2.605)\end{array}$ & $\begin{array}{l}-1.360 \\
(2.646)\end{array}$ \\
\hline $\begin{array}{l}\text { Under } 1 \text { - Reason V\&W\&X\&Y\&Z } \\
\text { External causes of morbidity and mortality }\end{array}$ & $\begin{array}{l}-0.541 \\
(5.143)\end{array}$ & $\begin{array}{l}-1.395 \\
(3.739) \\
\end{array}$ & $\begin{array}{l}-0.967 \\
(3.685) \\
\end{array}$ \\
\hline First-stage regression & $\begin{array}{c}2.850^{* * *} \\
(0.640)\end{array}$ & $\begin{array}{c}3.174 * * * \\
(0.792)\end{array}$ & $\begin{array}{c}3.251^{* * *} \\
(0.819)\end{array}$ \\
\hline F-statistics & 19.839 & 16.148 & 16.370 \\
\hline \multicolumn{4}{|l|}{ Controls for } \\
\hline Year Fixed Effects & Yes & Yes & Yes \\
\hline Province Fixed Effects & Yes & Yes & Yes \\
\hline 5 Region Linear Time Trends & No & Yes & No \\
\hline 5 Region-Year Fixed Effects & No & No & Yes \\
\hline
\end{tabular}

Notes: The sample includes 81 provinces in the 2013-2016 period. In all regressions, there are 324 observations. Each cell shows the estimates for the key variable of interest: the ratio of migrants to natives. The 2SLS regression instruments the key variable of interest using a distance-based cross country instrument. The regressions include province and year fixed effect controls and a set of geographical-area and year specific control variables as indicated above. The set of province-specific control variables included in the regressions are a set of geographical-area and year specific control variables as indicated above, the ratios of women with different levels of educational attainment (primary or secondary school, high school, and university or higher), the average household size, literacy rate, the fraction of women nevermarried, the average age of first-marriage for women, and the logarithm of GDP per capita. Regressions are weighted using province populations. Standard errors, given in parentheses, are clustered at the province level. *,**, or *** indicates significance at the $10 \%, 5 \%$ and $1 \%$ levels, respectively. 


\section{Figures}

Figure 1: Health Outcomes for Turkey in International Comparison (Source: WDI)

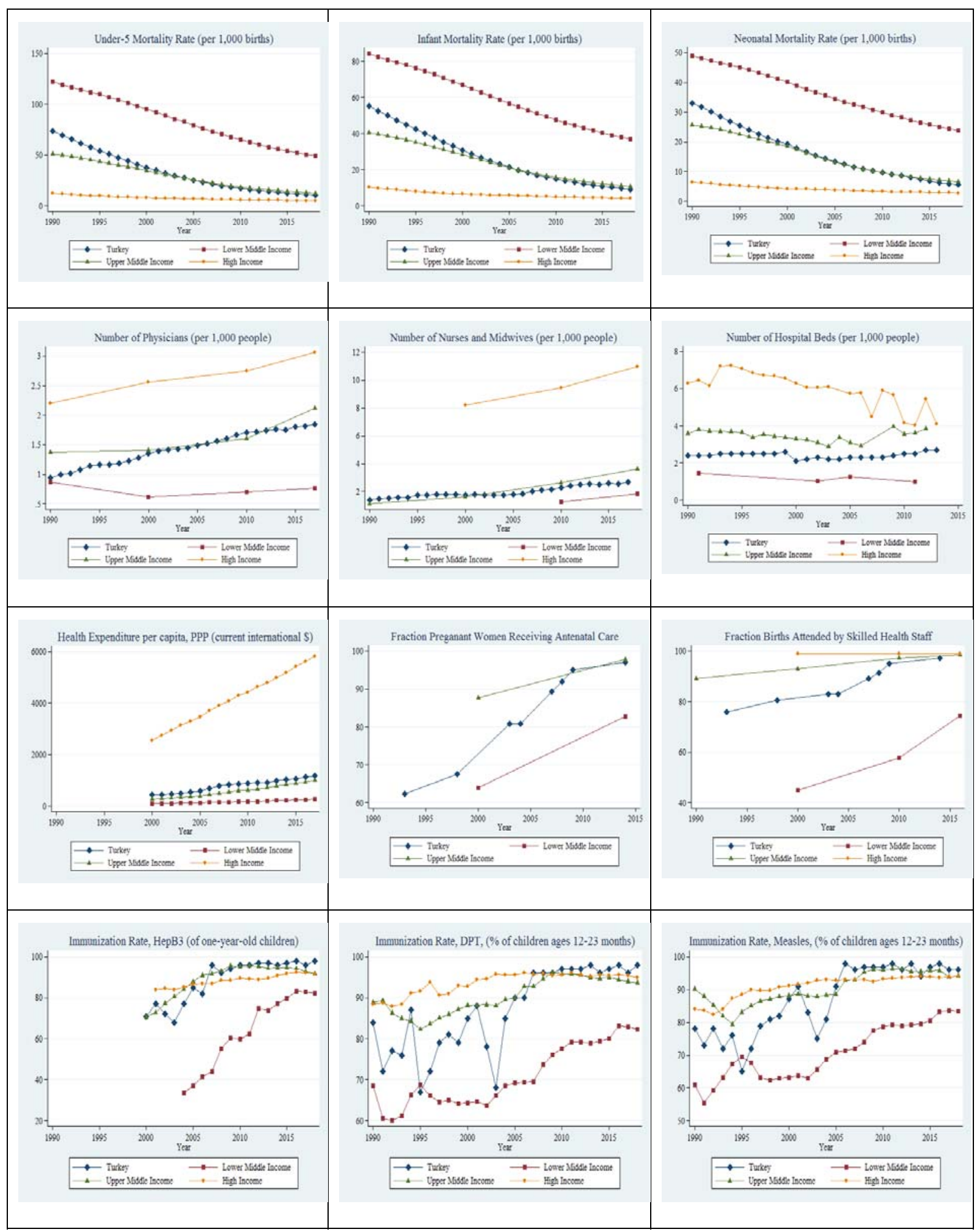


Figure 2: Ratio of Refugees to Natives across 81 Provinces, 2013-2017

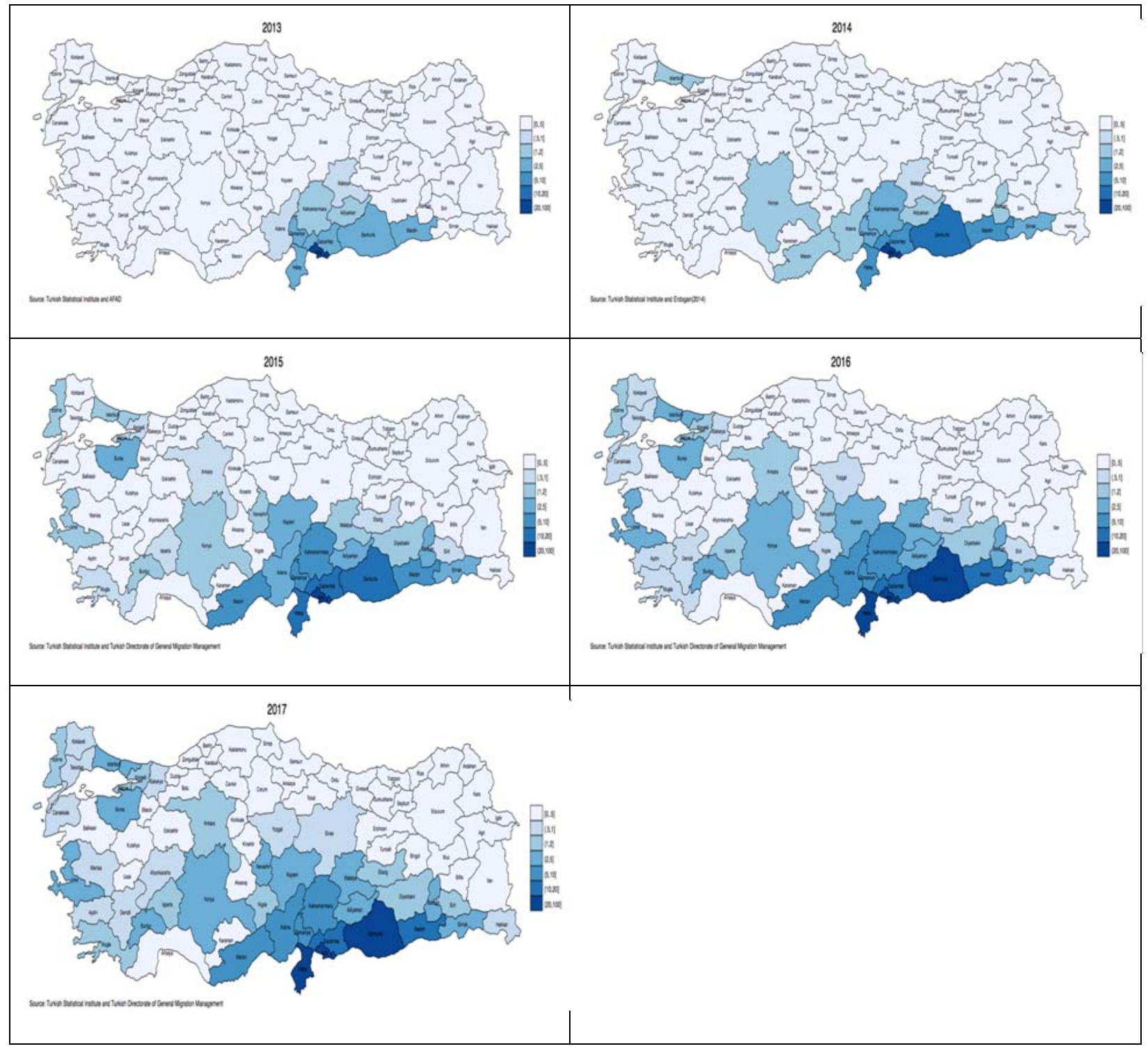




\section{Appendix Tables and Figures}

Table A1: Effect of Refugees on the Health Sector Infrastructure with Alternative Subsamples, 2SLS Estimates

\begin{tabular}{|c|c|c|c|c|c|c|c|c|c|}
\hline & $(1)$ & $(2)$ & (3) & (4) & $(5)$ & $(6)$ & (7) & $(8)$ & (9) \\
\hline $\begin{array}{l}\text { Dependent Variable (per capita) } \\
\text { (in logarithmic form) }\end{array}$ & A) Excl & udes Istanbul & Region & \multicolumn{3}{|c|}{$\begin{array}{l}\text { B) Excludes Western Turkey } \\
\text { (Istanbul, West Marmara, East } \\
\text { Marmara and Aegean Regions) }\end{array}$} & \multicolumn{3}{|c|}{$\begin{array}{l}\text { C) Includes Mediterranean, Northeast } \\
\text { Anatolia, Central East Anatolia and } \\
\text { Southeast Anatolia Regions }\end{array}$} \\
\hline \multicolumn{10}{|c|}{ PANEL I - Data time period: 2009-17 } \\
\hline Doctors & $\begin{array}{c}-0.809 * * * \\
(0.236)\end{array}$ & $\begin{array}{c}-0.807 * * * \\
(0.273)\end{array}$ & $\begin{array}{c}-0.755^{* * *} \\
(0.258)\end{array}$ & $\begin{array}{c}-0.713^{* * *} \\
(0.223)\end{array}$ & $\begin{array}{c}-0.874^{* * *} \\
(0.310)\end{array}$ & $\begin{array}{c}-0.819^{* * *} \\
(0.289)\end{array}$ & $\begin{array}{l}-0.550^{*} \\
(0.305)\end{array}$ & $\begin{array}{l}-0.546^{*} \\
(0.310)\end{array}$ & $\begin{array}{l}-0.537^{*} \\
(0.300)\end{array}$ \\
\hline Nurses & $\begin{array}{l}-0.140 \\
(0.281)\end{array}$ & $\begin{array}{l}-0.233 \\
(0.218)\end{array}$ & $\begin{array}{l}-0.267 \\
(0.210)\end{array}$ & $\begin{array}{l}-0.007 \\
(0.294)\end{array}$ & $\begin{array}{l}-0.152 \\
(0.199)\end{array}$ & $\begin{array}{l}-0.215 \\
(0.201)\end{array}$ & $\begin{array}{c}0.046 \\
(0.305)\end{array}$ & $\begin{array}{c}0.014 \\
(0.263)\end{array}$ & $\begin{array}{c}0.057 \\
(0.244)\end{array}$ \\
\hline Midwives & $\begin{array}{c}-0.666^{* *} \\
(0.255)\end{array}$ & $\begin{array}{c}-0.884^{* * *} \\
(0.247)\end{array}$ & $\begin{array}{c}-1.000^{* * *} \\
(0.281)\end{array}$ & $\begin{array}{c}-0.794 * * * \\
(0.239)\end{array}$ & $\begin{array}{c}-0.867 * * * \\
(0.257)\end{array}$ & $\begin{array}{c}-0.925^{* * *} \\
(0.284)\end{array}$ & $\begin{array}{c}-0.815^{* * *} \\
(0.279)\end{array}$ & $\begin{array}{c}-0.811^{* * *} \\
(0.277)\end{array}$ & $\begin{array}{c}-0.837 * * * \\
(0.299)\end{array}$ \\
\hline Hospital Beds & $\begin{array}{c}0.001 \\
(0.316)\end{array}$ & $\begin{array}{l}-0.002 \\
(0.231)\end{array}$ & $\begin{array}{c}0.026 \\
(0.240)\end{array}$ & $\begin{array}{c}0.220 \\
(0.254)\end{array}$ & $\begin{array}{c}0.121 \\
(0.208)\end{array}$ & $\begin{array}{c}0.136 \\
(0.218)\end{array}$ & $\begin{array}{c}0.135 \\
(0.295)\end{array}$ & $\begin{array}{c}0.100 \\
(0.253)\end{array}$ & $\begin{array}{c}0.141 \\
(0.250)\end{array}$ \\
\hline Hospitals & $\begin{array}{l}-0.424 \\
(0.261)\end{array}$ & $\begin{array}{c}-0.444^{* *} \\
(0.206)\end{array}$ & $\begin{array}{c}-0.499 * * \\
(0.226)\end{array}$ & $\begin{array}{c}-0.538^{* *} \\
(0.252)\end{array}$ & $\begin{array}{l}-0.456^{* *} \\
(0.207)\end{array}$ & $\begin{array}{l}-0.433^{*} \\
(0.226)\end{array}$ & $\begin{array}{c}-0.501 * * \\
(0.235)\end{array}$ & $\begin{array}{c}-0.494 * * \\
(0.231)\end{array}$ & $\begin{array}{c}-0.507 * * \\
(0.229)\end{array}$ \\
\hline First-stage & $\begin{array}{c}2.579 * * * \\
(0.445)\end{array}$ & $\begin{array}{c}2.797 * * * \\
(0.570)\end{array}$ & $\begin{array}{c}2.806^{* * *} \\
(0.618)\end{array}$ & $\begin{array}{c}2.744 * * * \\
(0.541)\end{array}$ & $\begin{array}{c}2.787 * * * \\
(0.604)\end{array}$ & $\begin{array}{c}2.785 * * * \\
(0.647)\end{array}$ & $\begin{array}{c}2.676^{* * *} \\
(0.614)\end{array}$ & $\begin{array}{c}2.683 * * * \\
(0.635)\end{array}$ & $\begin{array}{c}2.701 * * * \\
(0.639)\end{array}$ \\
\hline F-statistics & 33.413 & 23.976 & 20.929 & 25.437 & 21.168 & 18.895 & 18.652 & 17.625 & 18.407 \\
\hline \multicolumn{10}{|c|}{ PANEL II - Data time period: 2013-16 } \\
\hline Pediatricians & $\begin{array}{l}0.872^{*} \\
(0.479)\end{array}$ & $\begin{array}{c}0.745 \\
(0.511)\end{array}$ & $\begin{array}{c}0.874 \\
(0.558)\end{array}$ & $\begin{array}{l}1.040^{*} \\
(0.556)\end{array}$ & $\begin{array}{c}0.868 \\
(0.562)\end{array}$ & $\begin{array}{c}0.935 \\
(0.616)\end{array}$ & $\begin{array}{c}0.998 \\
(0.630)\end{array}$ & $\begin{array}{c}0.907 \\
(0.687)\end{array}$ & $\begin{array}{c}0.912 \\
(0.728)\end{array}$ \\
\hline First-stage & $\begin{array}{c}2.902^{* * * *} \\
(0.583)\end{array}$ & $\begin{array}{c}3.153 * * * \\
(0.731)\end{array}$ & $\begin{array}{c}3.199^{* * * *} \\
(0.803)\end{array}$ & $\begin{array}{c}3.025^{* * * *} \\
(0.675)\end{array}$ & $\begin{array}{c}3.044 * * * \\
(0.726)\end{array}$ & $\begin{array}{c}3.069^{* * *} \\
(0.808)\end{array}$ & $\begin{array}{c}2.919 * * * \\
(0.701)\end{array}$ & $\begin{array}{c}2.881 * * * \\
(0.704)\end{array}$ & $\begin{array}{c}2.878 * * * \\
(0.779)\end{array}$ \\
\hline F-statistics & 25.174 & 19.033 & 18.651 & 20.549 & 18.147 & 17.510 & 18.222 & 17.864 & 17.414 \\
\hline \multicolumn{10}{|c|}{ PANEL III - Data time period: 2014-17 } \\
\hline $\begin{array}{l}\text { Adult Intensive } \\
\text { Care Beds }\end{array}$ & $\begin{array}{l}-0.105 \\
(0.623)\end{array}$ & $\begin{array}{l}-1.160^{*} \\
(0.660)\end{array}$ & $\begin{array}{l}-1.071 \\
(0.659)\end{array}$ & $\begin{array}{l}-0.007 \\
(0.674)\end{array}$ & $\begin{array}{l}-1.047 \\
(0.662)\end{array}$ & $\begin{array}{l}-0.927 \\
(0.642)\end{array}$ & $\begin{array}{l}-0.522 \\
(0.757)\end{array}$ & $\begin{array}{l}-0.522 \\
(0.660)\end{array}$ & $\begin{array}{l}-0.308 \\
(0.526)\end{array}$ \\
\hline $\begin{array}{l}\text { Neonatal Intensive } \\
\text { Care Beds }\end{array}$ & $\begin{array}{c}0.503 \\
(1.054)\end{array}$ & $\begin{array}{l}-0.700 \\
(0.924)\end{array}$ & $\begin{array}{l}-0.290 \\
(0.907)\end{array}$ & $\begin{array}{c}0.264 \\
(1.226)\end{array}$ & $\begin{array}{l}-0.476 \\
(0.978)\end{array}$ & $\begin{array}{c}0.016 \\
(0.935)\end{array}$ & $\begin{array}{l}-0.255 \\
(1.463)\end{array}$ & $\begin{array}{l}-0.255 \\
(1.349)\end{array}$ & $\begin{array}{l}-0.132 \\
(1.279)\end{array}$ \\
\hline First-stage & $\begin{array}{c}3.927 * * * \\
(0.761)\end{array}$ & $\begin{array}{c}4.294^{* * *} \\
(0.927)\end{array}$ & $\begin{array}{c}4.287^{* * *} \\
(1.030)\end{array}$ & $\begin{array}{c}4.136^{* * *} \\
(0.929)\end{array}$ & $\begin{array}{c}4.150^{* * *} \\
(0.988)\end{array}$ & $\begin{array}{c}4.127 * * * \\
(1.116)\end{array}$ & $\begin{array}{l}3.911 * * \\
(1.208))\end{array}$ & $\begin{array}{c}3.911 * * * \\
(1.142)\end{array}$ & $\begin{array}{l}3.916^{* *} \\
(1.314)\end{array}$ \\
\hline F-statistics & 27.061 & 21.925 & 20.382 & 20.288 & 18.219 & 16.597 & 11.020 & 12.502 & 11.337 \\
\hline \multicolumn{10}{|l|}{ Controls for } \\
\hline Year FE & Yes & Yes & Yes & Yes & Yes & Yes & Yes & Yes & Yes \\
\hline Province FE & Yes & Yes & Yes & Yes & Yes & Yes & Yes & Yes & Yes \\
\hline 5 Region Trends & No & Yes & No & No & Yes & No & No & Yes & No \\
\hline 5 Region-Year FE & No & No & Yes & No & No & Yes & No & No & Yes \\
\hline
\end{tabular}

Notes: Data come from TurkStat. The sample includes the 2009-2017 period excluding year 2012. Panel (A) excludes Istanbul (NUTS1 region 1), panel (B) excludes western Turkey (NUTS1 regions 1-4), and panel (C) includes NUTS1 region 7 (the Mediterranean Region) and NUTS1 regions 10-12 (eastern Turkey). The number of observations is 640 in panel (1A), 472 in panel (1B), 256 in panel (1C), 320 in panel (2A) and (3A), 236 in panel (2B) and (3B), 128 in panel (2C) and (3C). Each cell comes from a separate regression and shows the estimates for the ratio of migrants to natives. The key variable of interest is instrumented using a distance-based cross-country instrument. The set of province-specific control variables included in the regressions are a set of geographical-area and year specific control variables as indicated above, the ratios of women with different levels of educational attainment (primary or secondary school, high school, and university or higher), the average household size, literacy rate, the fraction of women never-married, the average age of first-marriage for women, and the logarithm of GDP per capita. Regressions are weighted using province populations. Standard errors, given in parentheses, are clustered at the province level. *, **, or *** indicates significance at the $10 \%, 5 \%$ and $1 \%$ levels, respectively. 
Table A2: Effect of Refugees on Native Mortality with Alternative Subsamples, 2SLS Estimates

\begin{tabular}{|c|c|c|c|c|c|c|c|c|c|}
\hline \multicolumn{10}{|c|}{ Dependent Variable: Mortality Rate (in logarithmic form) } \\
\hline \multirow[b]{2}{*}{ Age/Month/Day Period } & \multicolumn{3}{|c|}{ A) Excludes Istanbul Region $(\mathrm{N}=640)$} & \multicolumn{3}{|c|}{$\begin{array}{l}\text { B) Excludes Western Turkey (Istanbul, } \\
\text { West Marmara, East Marmara and } \\
\text { Aegean Regions) }(\mathrm{N}=472)\end{array}$} & \multicolumn{3}{|c|}{$\begin{array}{l}\text { C) Includes Mediterranean, Northeast } \\
\text { Anatolia, Central East Anatolia and } \\
\text { Southeast Anatolia Regions }(\mathrm{N}=256)\end{array}$} \\
\hline & $(1)$ & $(2)$ & (3) & (4) & $(5)$ & $(6)$ & $(7)$ & $(8)$ & (9) \\
\hline Under Age 1 & $\begin{array}{l}-0.058 \\
(0.309)\end{array}$ & $\begin{array}{l}-0.387 \\
(0.373)\end{array}$ & $\begin{array}{c}-0.106 \\
(0.385)\end{array}$ & $\begin{array}{l}-0.124 \\
(0.397)\end{array}$ & $\begin{array}{l}-0.170 \\
(0.357)\end{array}$ & $\begin{array}{c}0.002 \\
(0.388)\end{array}$ & $\begin{array}{l}-0.405 \\
(0.425)\end{array}$ & $\begin{array}{l}-0.457 \\
(0.394)\end{array}$ & $\begin{array}{l}-0.439 \\
(0.394)\end{array}$ \\
\hline Under Age 5 & $\begin{array}{c}0.229 \\
(0.245)\end{array}$ & $\begin{array}{l}-0.070 \\
(0.288)\end{array}$ & $\begin{array}{c}0.198 \\
(0.298)\end{array}$ & $\begin{array}{c}0.145 \\
(0.338)\end{array}$ & $\begin{array}{c}0.144 \\
(0.276)\end{array}$ & $\begin{array}{c}0.328 \\
(0.307)\end{array}$ & $\begin{array}{c}-0.020 \\
(0.324)\end{array}$ & $\begin{array}{l}-0.066 \\
(0.302)\end{array}$ & $\begin{array}{l}-0.054 \\
(0.295)\end{array}$ \\
\hline Day 0 & $\begin{array}{l}-0.382 \\
(1.361)\end{array}$ & $\begin{array}{l}-1.014 \\
(1.511)\end{array}$ & $\begin{array}{c}-0.571 \\
(1.482)\end{array}$ & $\begin{array}{l}-1.021 \\
(1.659)\end{array}$ & $\begin{array}{c}-0.696 \\
(1.525)\end{array}$ & $\begin{array}{l}-0.420 \\
(1.478)\end{array}$ & $\begin{array}{l}-1.572 \\
(1.732)\end{array}$ & $\begin{array}{c}-1.624 \\
(1.664)\end{array}$ & $\begin{array}{c}-1.377 \\
(1.559)\end{array}$ \\
\hline Days 1-6 & $\begin{array}{c}0.008 \\
(0.487)\end{array}$ & $\begin{array}{l}-0.526 \\
(0.522)\end{array}$ & $\begin{array}{c}-0.363 \\
(0.622)\end{array}$ & $\begin{array}{c}0.110 \\
(0.588)\end{array}$ & $\begin{array}{l}-0.361 \\
(0.547)\end{array}$ & $\begin{array}{l}-0.239 \\
(0.647)\end{array}$ & $\begin{array}{c}-0.992 \\
(0.705)\end{array}$ & $\begin{array}{l}-1.066 \\
(0.719)\end{array}$ & $\begin{array}{l}-1.084 \\
(0.731)\end{array}$ \\
\hline Week 1 & $\begin{array}{l}-0.033 \\
(0.616)\end{array}$ & $\begin{array}{l}-0.630 \\
(0.707)\end{array}$ & $\begin{array}{c}-0.382 \\
(0.775)\end{array}$ & $\begin{array}{c}-0.147 \\
(0.754)\end{array}$ & $\begin{array}{c}-0.397 \\
(0.713)\end{array}$ & $\begin{array}{l}-0.241 \\
(0.778)\end{array}$ & $\begin{array}{l}-1.120 \\
(0.849)\end{array}$ & $\begin{array}{l}-1.177 \\
(0.824)\end{array}$ & $\begin{array}{l}-1.109 \\
(0.826)\end{array}$ \\
\hline Days 7-29 & $\begin{array}{l}-0.638 \\
(0.559)\end{array}$ & $\begin{array}{l}-0.701 \\
(0.612)\end{array}$ & $\begin{array}{c}-0.081 \\
(0.484)\end{array}$ & $\begin{array}{l}-0.723 \\
(0.622)\end{array}$ & $\begin{array}{l}-0.445 \\
(0.571)\end{array}$ & $\begin{array}{c}0.038 \\
(0.484)\end{array}$ & $\begin{array}{l}-0.321 \\
(0.538)\end{array}$ & $\begin{array}{l}-0.391 \\
(0.468)\end{array}$ & $\begin{array}{l}-0.337 \\
(0.435)\end{array}$ \\
\hline Days $1-29$ & $\begin{array}{l}-0.179 \\
(0.415)\end{array}$ & $\begin{array}{l}-0.561 \\
(0.477)\end{array}$ & $\begin{array}{l}-0.269 \\
(0.514)\end{array}$ & $\begin{array}{c}-0.148 \\
(0.495)\end{array}$ & $\begin{array}{l}-0.360 \\
(0.465)\end{array}$ & $\begin{array}{l}-0.131 \\
(0.521)\end{array}$ & $\begin{array}{c}-0.711 \\
(0.568)\end{array}$ & $\begin{array}{c}-0.786 \\
(0.547)\end{array}$ & $\begin{array}{l}-0.781 \\
(0.552)\end{array}$ \\
\hline Under Month 1 & $\begin{array}{l}-0.132 \\
(0.530)\end{array}$ & $\begin{array}{l}-0.595 \\
(0.621)\end{array}$ & $\begin{array}{c}-0.266 \\
(0.641)\end{array}$ & $\begin{array}{l}-0.250 \\
(0.654)\end{array}$ & $\begin{array}{c}-0.351 \\
(0.607)\end{array}$ & $\begin{array}{l}-0.120 \\
(0.638)\end{array}$ & $\begin{array}{c}-0.832 \\
(0.702)\end{array}$ & $\begin{array}{c}-0.893 \\
(0.657)\end{array}$ & $\begin{array}{c}-0.834 \\
(0.651)\end{array}$ \\
\hline Month 1-11 & $\begin{array}{c}-0.153 \\
(0.187) \\
\end{array}$ & $\begin{array}{l}-0.195 \\
(0.236) \\
\end{array}$ & $\begin{array}{c}0.024 \\
(0.252)\end{array}$ & $\begin{array}{c}-0.073 \\
(0.186) \\
\end{array}$ & $\begin{array}{c}-0.057 \\
(0.223)\end{array}$ & $\begin{array}{c}0.047 \\
(0.257) \\
\end{array}$ & $\begin{array}{c}0.156 \\
(0.248) \\
\end{array}$ & $\begin{array}{c}0.128 \\
(0.274)\end{array}$ & $\begin{array}{c}0.093 \\
(0.258) \\
\end{array}$ \\
\hline First-stage regression & $\begin{array}{c}2.620 * * * \\
(0.489)\end{array}$ & $\begin{array}{c}2.848 * * * \\
(0.614)\end{array}$ & $\begin{array}{c}2.868 * * * \\
(0.666)\end{array}$ & $\begin{array}{c}2.778^{* * *} \\
(0.578)\end{array}$ & $\begin{array}{c}2.840 * * * \\
(0.642)\end{array}$ & $\begin{array}{c}2.845 * * * \\
(0.686)\end{array}$ & $\begin{array}{c}2.737 * * * \\
(0.642)\end{array}$ & $\begin{array}{c}2.750 * * * \\
(0.664)\end{array}$ & $\begin{array}{c}2.770 * * * \\
(0.668)\end{array}$ \\
\hline F-statistics & 28.448 & 21.394 & 18.876 & 22.897 & 19.397 & 17.539 & 17.839 & 16.921 & 17.673 \\
\hline Ages: $65+$ & $\begin{array}{c}0.085 \\
(0.069) \\
\end{array}$ & $\begin{array}{c}0.042 \\
(0.059) \\
\end{array}$ & $\begin{array}{c}0.031 \\
(0.061)\end{array}$ & $\begin{array}{c}0.053 \\
(0.072) \\
\end{array}$ & $\begin{array}{c}0.052 \\
(0.065)\end{array}$ & $\begin{array}{c}0.062 \\
(0.067)\end{array}$ & $\begin{array}{c}0.086 \\
(0.079) \\
\end{array}$ & $\begin{array}{c}0.100 \\
(0.079)\end{array}$ & $\begin{array}{c}0.102 \\
(0.083) \\
\end{array}$ \\
\hline First-stage regression & $\begin{array}{c}2.694 * * * \\
(0.518)\end{array}$ & $\begin{array}{c}2.928 * * * \\
(0.678)\end{array}$ & $\begin{array}{c}2.934 * * * \\
(0.733)\end{array}$ & $\begin{array}{c}2.900^{* * *} \\
(0.646)\end{array}$ & $\begin{array}{c}2.936 * * * \\
(0.722)\end{array}$ & $\begin{array}{c}2.925 * * * \\
(0.773)\end{array}$ & $\begin{array}{c}2.814 * * * \\
(0.740)\end{array}$ & $\begin{array}{c}2.819^{* * *} \\
(0.766)\end{array}$ & $\begin{array}{c}2.833 * * * \\
(0.779)\end{array}$ \\
\hline F-statistics & 26.853 & 18.521 & 16.283 & 19.951 & 16.431 & 14.615 & 14.202 & 13.360 & 13.603 \\
\hline Ages: $75+$ & $\begin{array}{c}0.113 \\
(0.136) \\
\end{array}$ & $\begin{array}{c}0.031 \\
(0.151) \\
\end{array}$ & $\begin{array}{c}0.020 \\
(0.158) \\
\end{array}$ & $\begin{array}{c}0.090 \\
(0.157) \\
\end{array}$ & $\begin{array}{c}0.080 \\
(0.154) \\
\end{array}$ & $\begin{array}{c}0.072 \\
(0.162) \\
\end{array}$ & $\begin{array}{c}0.160 \\
(0.181) \\
\end{array}$ & $\begin{array}{c}0.154 \\
(0.179) \\
\end{array}$ & $\begin{array}{c}0.144 \\
(0.187) \\
\end{array}$ \\
\hline First-stage regression & $\begin{array}{c}2.735 * * * \\
(0.560)\end{array}$ & $\begin{array}{c}2.983 * * * \\
(0.732)\end{array}$ & $\begin{array}{c}2.992 * * * \\
(0.792)\end{array}$ & $\begin{array}{c}2.955^{* * * *} \\
(0.693)\end{array}$ & $\begin{array}{c}3.006 * * * \\
(0.775)\end{array}$ & $\begin{array}{c}2.996 * * * \\
(0.830)\end{array}$ & $\begin{array}{c}2.894 * * * \\
(0.787)\end{array}$ & $\begin{array}{c}2.905^{* * *} \\
(0.818)\end{array}$ & $\begin{array}{c}2.916 * * * \\
(0.659)\end{array}$ \\
\hline F-statistics & 23.648 & 16.523 & 14.528 & 18.032 & 14.936 & 13.280 & 13.268 & 12.443 & 12.590 \\
\hline All Ages & $\begin{array}{l}0.167 * \\
(0.087) \\
\end{array}$ & $\begin{array}{l}-0.012 \\
(0.070) \\
\end{array}$ & $\begin{array}{c}0.005 \\
(0.076) \\
\end{array}$ & $\begin{array}{c}0.057 \\
(0.080) \\
\end{array}$ & $\begin{array}{l}-0.030 \\
(0.076) \\
\end{array}$ & $\begin{array}{c}0.019 \\
(0.081) \\
\end{array}$ & $\begin{array}{c}0.048 \\
(0.105) \\
\end{array}$ & $\begin{array}{c}0.041 \\
(0.102) \\
\end{array}$ & $\begin{array}{c}0.052 \\
(0.103) \\
\end{array}$ \\
\hline First-stage regression & $\begin{array}{c}2.579 * * * \\
(0.445)\end{array}$ & $\begin{array}{c}2.797 * * * \\
(0.570)\end{array}$ & $\begin{array}{c}2.806 * * * \\
(0.618)\end{array}$ & $\begin{array}{c}2.744 * * * \\
(0.5410)\end{array}$ & $\begin{array}{c}2.787 * * * \\
(0.604)\end{array}$ & $\begin{array}{c}2.785 * * * \\
(0.647)\end{array}$ & $\begin{array}{c}2.676^{* * *} \\
(0.614)\end{array}$ & $\begin{array}{c}2.683 * * * \\
(0.635)\end{array}$ & $\begin{array}{c}2.701 * * * \\
(0.639)\end{array}$ \\
\hline F-statistics & 33.413 & 23.976 & 20.929 & 25.437 & 21.168 & 18.895 & 18.652 & 17.625 & 18.407 \\
\hline \multicolumn{10}{|l|}{ Controls for } \\
\hline Year FE & Yes & Yes & Yes & Yes & Yes & Yes & Yes & Yes & Yes \\
\hline Province FE & Yes & Yes & Yes & Yes & Yes & Yes & Yes & Yes & Yes \\
\hline 5 Region Trends & No & Yes & No & No & Yes & No & No & Yes & No \\
\hline 5 Region-Year FE & No & No & Yes & No & No & Yes & No & No & Yes \\
\hline
\end{tabular}

Notes: Data come from TurkStat. The sample includes the 2009-2017 period excluding year 2012. Panel (A) excludes Istanbul (NUTS1 region 1), panel (B) excludes western Turkey (NUTS1 regions 1-4), and panel (C) includes NUTS1 region 7 (the Mediterranean Region) and NUTS1 regions 10-12 (eastern Turkey). Each cell comes from a separate regression and shows the estimates for the ratio of migrants to natives. The key variable of interest is instrumented using a distance-based cross-country instrument. The set of province-specific control variables included in the regressions are a set of geographical-area and year specific control variables as indicated above, the ratios of women with different levels of educational attainment (primary or secondary school, high school, and university or higher), the average household size, literacy rate, the fraction of women never-married, the average age of first-marriage for women, and the logarithm of GDP per capita. Regressions are weighted using the number of births by province in infant and child mortality regressions and using the populations of age groups by province in mortality regressions by age. Standard errors, given in parentheses, are clustered at the province level. *, **, or *** indicates significance at the $10 \%, 5 \%$ and $1 \%$ levels, respectively. 
Table A3: Effect of Refugees on the Health Sector Infrastructure with an Alternative Instrument

\begin{tabular}{|c|c|c|c|c|c|c|}
\hline \multirow{2}{*}{$\begin{array}{l}\text { Dependent Variable (per capita) } \\
\text { (in logarithmic form) }\end{array}$} & $(1)$ & $(2)$ & (3) & $(4)$ & $(5)$ & $(6)$ \\
\hline & \multicolumn{3}{|c|}{ OLS } & \multicolumn{3}{|c|}{ 2SLS } \\
\hline \multicolumn{7}{|c|}{ PANEL A - Data time period: 2009-17 } \\
\hline Doctors & $\begin{array}{c}-0.747 * * * \\
(0.209)\end{array}$ & $\begin{array}{c}-0.782 * * * \\
(0.241)\end{array}$ & $\begin{array}{c}-0.729 * * * \\
(0.222)\end{array}$ & $\begin{array}{c}-1.003 * * * \\
(0.289)\end{array}$ & $\begin{array}{c}-1.033^{* * *} \\
(0.323)\end{array}$ & $\begin{array}{c}-0.929 * * * \\
(0.298)\end{array}$ \\
\hline Nurses & $\begin{array}{l}-0.278^{*} \\
(0.166)\end{array}$ & $\begin{array}{c}-0.295^{* *} \\
(0.140)\end{array}$ & $\begin{array}{c}-0.303 * * \\
(0.139)\end{array}$ & $\begin{array}{l}-0.323 \\
(0.385)\end{array}$ & $\begin{array}{l}-0.295 \\
(0.304)\end{array}$ & $\begin{array}{l}-0.261 \\
(0.265)\end{array}$ \\
\hline Midwives & $\begin{array}{c}-0.540^{* * *} \\
(0.182)\end{array}$ & $\begin{array}{c}-0.580 * * * \\
(0.203)\end{array}$ & $\begin{array}{c}-0.664 * * * \\
(0.225)\end{array}$ & $\begin{array}{c}-0.546^{* *} \\
(0.274)\end{array}$ & $\begin{array}{c}-0.666^{* * *} \\
(0.248)\end{array}$ & $\begin{array}{c}-0.949 * * * \\
(0.246)\end{array}$ \\
\hline Hospital Beds & $\begin{array}{l}-0.082 \\
(0.177)\end{array}$ & $\begin{array}{l}-0.102 \\
(0.149)\end{array}$ & $\begin{array}{l}-0.103 \\
(0.159)\end{array}$ & $\begin{array}{l}-0.022 \\
(0.304)\end{array}$ & $\begin{array}{l}-0.006 \\
(0.228)\end{array}$ & $\begin{array}{c}0.060 \\
(0.211)\end{array}$ \\
\hline Hospitals & $\begin{array}{c}-0.471 * * \\
(0.215)\end{array}$ & $\begin{array}{c}-0.502 * * \\
(0.220)\end{array}$ & $\begin{array}{c}-0.524 * * \\
(0.247)\end{array}$ & $\begin{array}{l}-0.443 \\
(0.305)\end{array}$ & $\begin{array}{c}-0.547 * * \\
(0.224)\end{array}$ & $\begin{array}{c}-0.586 * * \\
(0.242)\end{array}$ \\
\hline First-stage regression & & & & $\begin{array}{c}1.952 * * * \\
(0.300)\end{array}$ & $\begin{array}{l}2.168^{* * *} \\
(0.378)\end{array}$ & $\begin{array}{c}2.289^{* * *} \\
(0.444)\end{array}$ \\
\hline F-statistics & & & & 42.069 & 32.748 & 27.048 \\
\hline \multicolumn{7}{|c|}{ PANEL B - Data time period: 2013-16 } \\
\hline Pediatricians & $\begin{array}{l}0.833^{*} \\
(0.450)\end{array}$ & $\begin{array}{l}0.798^{*} \\
(0.449)\end{array}$ & $\begin{array}{l}0.785^{*} \\
(0.410)\end{array}$ & $\begin{array}{c}1.005 * * \\
(0.482)\end{array}$ & $\begin{array}{l}1.127 * * \\
(0.551)\end{array}$ & $\begin{array}{l}1.058^{*} \\
(0.572)\end{array}$ \\
\hline First-stage regression & & & & $\begin{array}{c}1.866^{* * *} \\
(0.325)\end{array}$ & $\begin{array}{c}2.164 * * * \\
(0.431)\end{array}$ & $\begin{array}{c}2.158 * * * \\
(0.481)\end{array}$ \\
\hline F-statistics & & & & 33.561 & 25.719 & 23.586 \\
\hline \multicolumn{7}{|c|}{ PANEL C - Data time period: 2014-17 } \\
\hline Adult Intensive Care Beds & $\begin{array}{l}-0.859 \\
(0.710)\end{array}$ & $\begin{array}{l}-1.140 \\
(0.757)\end{array}$ & $\begin{array}{l}-1.089 \\
(0.766)\end{array}$ & $\begin{array}{l}-0.138 \\
(0.641)\end{array}$ & $\begin{array}{l}-1.143 \\
(0.696)\end{array}$ & $\begin{array}{l}-1.083 \\
(0.712)\end{array}$ \\
\hline Neonatal Intensive Care Beds & $\begin{array}{l}-1.581 \\
(1.359)\end{array}$ & $\begin{array}{l}-1.308 \\
(1.223)\end{array}$ & $\begin{array}{l}-1.146 \\
(1.225)\end{array}$ & $\begin{array}{c}0.539 \\
(1.136)\end{array}$ & $\begin{array}{l}-0.393 \\
(0.983)\end{array}$ & $\begin{array}{l}-0.056 \\
(0.973)\end{array}$ \\
\hline First-stage regression & & & & $\begin{array}{c}2.870^{* * *} \\
(0.317)\end{array}$ & $\begin{array}{c}2.146 * * * \\
(0.417)\end{array}$ & $\begin{array}{c}2.136^{* * *} \\
(0.457)\end{array}$ \\
\hline F-statistics & & & & 35.374 & 27.044 & 25.630 \\
\hline \multicolumn{7}{|l|}{ Controls for } \\
\hline Year Fixed Effects & Yes & Yes & Yes & Yes & Yes & Yes \\
\hline Province Fixed Effects & Yes & Yes & Yes & Yes & Yes & Yes \\
\hline 5 Region Linear Time Trends & No & Yes & No & No & Yes & No \\
\hline 5 Region-Year Fixed Effects & No & No & Yes & No & No & Yes \\
\hline
\end{tabular}

Notes: Information on the health infrastructure variables is obtained from TurkStat. The full sample is for the 2009-17 period, excluding 2012, at the 81-province level. The number of observations is 648 in panel (A), whereas it is 324 in panel (B) and panel (C) as the variables in these panels are available for recent years only. Each cell shows the estimates for the ratio of migrants to natives. The 2SLS regression instruments the key variable of interest using the del Carpio-Wagner distance-based instrument. The set of province-specific control variables included in the regressions are a set of geographical-area and year specific control variables as indicated above, the ratios of women with different levels of educational attainment (primary or secondary school, high school, and university or higher), the average household size, literacy rate, the fraction of women never-married, the average age of firstmarriage for women, and the logarithm of GDP per capita. Regressions are weighted using province populations. Standard errors, given in parentheses, are clustered at the province level. *, **, or *** indicates significance at the $10 \%, 5 \%$ and $1 \%$ levels, respectively. 
Table A4: Effect of Refugees on Mortality Outcomes with an Alternative Instrument

\begin{tabular}{|c|c|c|c|c|c|c|}
\hline \multicolumn{7}{|c|}{ Dependent Variable: Mortality Rate (in logarithmic form) } \\
\hline \multirow[b]{2}{*}{ Age/Month/Day Period } & $(1)$ & (2) & (3) & (4) & (5) & (6) \\
\hline & \multicolumn{3}{|c|}{ OLS } & \multicolumn{3}{|c|}{ 2SLS } \\
\hline Under Age 1 & $\begin{array}{c}0.153 \\
(0.165)\end{array}$ & $\begin{array}{c}0.129 \\
(0.194)\end{array}$ & $\begin{array}{c}0.327 \\
(0.207)\end{array}$ & $\begin{array}{l}-0.369 \\
(0.427)\end{array}$ & $\begin{array}{l}-0.646 \\
(0.455)\end{array}$ & $\begin{array}{l}-0.031 \\
(0.377)\end{array}$ \\
\hline Under Age 5 & $\begin{array}{c}0.207 \\
(0.137)\end{array}$ & $\begin{array}{c}0.150 \\
(0.152)\end{array}$ & $\begin{array}{l}0.321^{*} \\
(0.162)\end{array}$ & $\begin{array}{l}-0.022 \\
(0.323)\end{array}$ & $\begin{array}{l}-0.315 \\
(0.344)\end{array}$ & $\begin{array}{c}0.203 \\
(0.298)\end{array}$ \\
\hline Day 0 & $\begin{array}{l}-0.237 \\
(0.641)\end{array}$ & $\begin{array}{l}-0.281 \\
(0.631)\end{array}$ & $\begin{array}{l}-0.017 \\
(0.639)\end{array}$ & $\begin{array}{l}-0.995 \\
(1.470)\end{array}$ & $\begin{array}{l}-1.602 \\
(1.557)\end{array}$ & $\begin{array}{c}-0.513 \\
(1.327)\end{array}$ \\
\hline Days 1-6 & $\begin{array}{c}0.316 \\
(0.333)\end{array}$ & $\begin{array}{c}0.218 \\
(0.363)\end{array}$ & $\begin{array}{c}0.353 \\
(0.388)\end{array}$ & $\begin{array}{l}-0.404 \\
(0.585)\end{array}$ & $\begin{array}{l}-0.762 \\
(0.575)\end{array}$ & $\begin{array}{l}-0.223 \\
(0.611)\end{array}$ \\
\hline Week 1 & $\begin{array}{c}0.166 \\
(0.352)\end{array}$ & $\begin{array}{c}0.063 \\
(0.362)\end{array}$ & $\begin{array}{c}0.229 \\
(0.395)\end{array}$ & $\begin{array}{l}-0.510 \\
(0.749)\end{array}$ & $\begin{array}{l}-0.971 \\
(0.775)\end{array}$ & $\begin{array}{l}-0.274 \\
(0.712)\end{array}$ \\
\hline Days 7-29 & $\begin{array}{l}-0.035 \\
(0.300)\end{array}$ & $\begin{array}{c}0.098 \\
(0.339)\end{array}$ & $\begin{array}{l}0.523 * \\
(0.266)\end{array}$ & $\begin{array}{l}-0.894 \\
(0.688)\end{array}$ & $\begin{array}{l}-0.995 \\
(0.741)\end{array}$ & $\begin{array}{c}0.050 \\
(0.494)\end{array}$ \\
\hline Days 1-29 & $\begin{array}{c}0.210 \\
(0.245)\end{array}$ & $\begin{array}{c}0.190 \\
(0.290)\end{array}$ & $\begin{array}{c}0.416 \\
(0.309)\end{array}$ & $\begin{array}{l}-0.534 \\
(0.551)\end{array}$ & $\begin{array}{l}-0.810 \\
(0.572)\end{array}$ & $\begin{array}{l}-0.127 \\
(0.510)\end{array}$ \\
\hline Under Month 1 & $\begin{array}{c}0.151 \\
(0.282)\end{array}$ & $\begin{array}{c}0.108 \\
(0.307)\end{array}$ & $\begin{array}{c}0.339 \\
(0.327)\end{array}$ & $\begin{array}{l}-0.547 \\
(0.675)\end{array}$ & $\begin{array}{l}-0.916 \\
(0.716)\end{array}$ & $\begin{array}{l}-0.146 \\
(0.605)\end{array}$ \\
\hline Month 1-11 & $\begin{array}{c}0.027 \\
(0.117) \\
\end{array}$ & $\begin{array}{c}0.054 \\
(0.141) \\
\end{array}$ & $\begin{array}{c}0.202 \\
(0.168) \\
\end{array}$ & $\begin{array}{l}-0.286 \\
(0.224) \\
\end{array}$ & $\begin{array}{l}-0.337 \\
(0.237) \\
\end{array}$ & $\begin{array}{c}0.053 \\
(0.249) \\
\end{array}$ \\
\hline First-stage regression & & & & $\begin{array}{c}2.009 * * * \\
(0.337)\end{array}$ & $\begin{array}{c}2.240^{* * *} \\
(0.417)\end{array}$ & $\begin{array}{c}2.374 * * * \\
(0.488)\end{array}$ \\
\hline F-statistics & & & & 35.342 & 28.745 & 24.019 \\
\hline Ages: $65+$ & $\begin{array}{c}0.012 \\
(0.045) \\
\end{array}$ & $\begin{array}{l}-0.020 \\
(0.042)\end{array}$ & $\begin{array}{l}-0.031 \\
(0.041)\end{array}$ & $\begin{array}{c}0.109 \\
(0.079) \\
\end{array}$ & $\begin{array}{c}0.075 \\
(0.075) \\
\end{array}$ & $\begin{array}{c}0.044 \\
(0.065)\end{array}$ \\
\hline First-stage regression & & & & $\begin{array}{c}1.987 * * * \\
(0.337)\end{array}$ & $\begin{array}{c}2.203 * * * \\
(0.437)\end{array}$ & $\begin{array}{c}2.311^{* * *} \\
(0.511)\end{array}$ \\
\hline F-statistics & & & & 34.568 & 25.297 & 20.760 \\
\hline Ages: $75+$ & $\begin{array}{l}-0.031 \\
(0.116) \\
\end{array}$ & $\begin{array}{l}-0.079 \\
(0.097) \\
\end{array}$ & $\begin{array}{l}-0.090 \\
(0.097)\end{array}$ & $\begin{array}{c}0.141 \\
(0.125)\end{array}$ & $\begin{array}{c}0.069 \\
(0.139)\end{array}$ & $\begin{array}{c}0.055 \\
(0.147)\end{array}$ \\
\hline First-stage regression & & & & $\begin{array}{c}2.045 * * * \\
(0.370)\end{array}$ & $\begin{array}{c}2.268 * * * \\
(0.481)\end{array}$ & $\begin{array}{c}2.382^{* * * *} \\
(0.564)\end{array}$ \\
\hline F-statistics & & & & 30.346 & 22.085 & 18.146 \\
\hline All Ages & $\begin{array}{c}0.026 \\
(0.061) \\
\end{array}$ & $\begin{array}{l}-0.056 \\
(0.054) \\
\end{array}$ & $\begin{array}{l}-0.049 \\
(0.054) \\
\end{array}$ & $\begin{array}{l}0.164 * \\
(0.091) \\
\end{array}$ & $\begin{array}{c}-0.031 \\
(0.069) \\
\end{array}$ & $\begin{array}{l}-0.031 \\
(0.075) \\
\end{array}$ \\
\hline First-stage regression & & & & $\begin{array}{c}1.952 * * * \\
(0.300)\end{array}$ & $\begin{array}{c}2.168 * * * \\
(0.378)\end{array}$ & $\begin{array}{c}2.289 * * * \\
(0.444)\end{array}$ \\
\hline F-statistics & & & & 42.069 & 32.748 & 27.048 \\
\hline \multicolumn{7}{|l|}{ Controls for } \\
\hline Year Fixed Effects & Yes & Yes & Yes & Yes & Yes & Yes \\
\hline Province Fixed Effects & Yes & Yes & Yes & Yes & Yes & Yes \\
\hline 5 Region Linear Time Trends & No & Yes & No & No & Yes & No \\
\hline 5 Region-Year Fixed Effects & No & No & Yes & No & No & Yes \\
\hline
\end{tabular}

Notes: Data come from TurkStat. The sample includes 81 provinces in the 2009-2017 period excluding year 2012. The number of observations is 648 . Each cell comes from a separate regression and shows the estimates for the ratio of migrants to natives. The 2SLS regression instruments the key variable of interest using the del CarpioWagner distance-based instrument. The set of province-specific control variables included in the regressions are a set of geographical-area and year specific control variables as indicated above, the ratios of women with different levels of educational attainment (primary or secondary school, high school, and university or higher), the average household size, literacy rate, the fraction of women never-married, the average age of first-marriage for women, and the logarithm of GDP per capita. Regressions are weighted using the number of births by province in infant and child mortality regressions and using the populations of age groups by province in mortality regressions by age. Standard errors, given in parentheses, are clustered at the province level. *, ${ }^{* *}$, or ${ }^{* * *}$ indicates significance at the $10 \%, 5 \%$ and $1 \%$ levels, respectively. 
Table A5: Effect of Refugees on the Health Sector Infrastructure - without Logarithmic Transformation of the Dependent Variable

\begin{tabular}{|c|c|c|c|c|c|c|}
\hline \multirow{2}{*}{$\begin{array}{l}\text { Dependent Variable } \\
\text { (per capita) }\end{array}$} & $(1)$ & $(2)$ & (3) & (4) & $(5)$ & (6) \\
\hline & \multicolumn{3}{|c|}{ OLS } & \multicolumn{3}{|c|}{ 2SLS } \\
\hline \multicolumn{7}{|c|}{ PANEL A - Data time period: 2009-17 } \\
\hline Doctors & $\begin{array}{c}-0.993 * * * \\
(0.262)\end{array}$ & $\begin{array}{c}-1.105^{* * *} \\
(0.340)\end{array}$ & $\begin{array}{c}-1.037 * * * \\
(0.311)\end{array}$ & $\begin{array}{c}-1.426^{* * *} \\
(0.490)\end{array}$ & $\begin{array}{c}-1.502 * * * \\
(0.524)\end{array}$ & $\begin{array}{c}-1.448 * * * \\
(0.527)\end{array}$ \\
\hline Nurses & $\begin{array}{c}-0.662 * * * \\
(0.238)\end{array}$ & $\begin{array}{c}-0.775^{* * *} \\
(0.262)\end{array}$ & $\begin{array}{c}-0.812 * * * \\
(0.253)\end{array}$ & $\begin{array}{l}-0.782 \\
(0.509)\end{array}$ & $\begin{array}{l}-0.902 * \\
(0.522)\end{array}$ & $\begin{array}{l}-0.984 * \\
(0.514)\end{array}$ \\
\hline Midwives & $\begin{array}{c}-0.264 * * * \\
(0.098)\end{array}$ & $\begin{array}{c}-0.259 * * * \\
(0.095)\end{array}$ & $\begin{array}{c}-0.311^{* * *} \\
(0.102)\end{array}$ & $\begin{array}{c}-0.366^{* *} \\
(0.147)\end{array}$ & $\begin{array}{c}-0.378^{* * *} \\
(0.138)\end{array}$ & $\begin{array}{c}-0.466^{* * *} \\
(0.164)\end{array}$ \\
\hline Hospital Beds & $\begin{array}{l}-0.384 \\
(0.331)\end{array}$ & $\begin{array}{l}-0.494 \\
(0.317)\end{array}$ & $\begin{array}{l}-0.495 \\
(0.317)\end{array}$ & $\begin{array}{l}-0.204 \\
(0.570)\end{array}$ & $\begin{array}{l}-0.341 \\
(0.514)\end{array}$ & $\begin{array}{l}-0.156 \\
(0.500)\end{array}$ \\
\hline Hospitals & $\begin{array}{l}-0.006 \\
(0.004)\end{array}$ & $\begin{array}{l}-0.006 \\
(0.003)\end{array}$ & $\begin{array}{l}-0.006 \\
(0.004)\end{array}$ & $\begin{array}{l}-0.008 \\
(0.005)\end{array}$ & $\begin{array}{c}-0.008^{* *} \\
(0.004)\end{array}$ & $\begin{array}{c}-0.009^{* *} \\
(0.004)\end{array}$ \\
\hline First-stage regression & & & & $\begin{array}{l}2.536^{* * *} \\
(0.445)\end{array}$ & $\begin{array}{c}2.795 * * * \\
(0.562)\end{array}$ & $\begin{array}{c}2.816^{* * * *} \\
(0.617)\end{array}$ \\
\hline F-statistics & & & & 32.184 & 24.588 & 21.154 \\
\hline \multicolumn{7}{|c|}{ PANEL B - Data time period: 2013-16 } \\
\hline Pediatricians & $\begin{array}{l}0.027^{*} \\
(0.015)\end{array}$ & $\begin{array}{l}0.027^{*} \\
(0.015)\end{array}$ & $\begin{array}{l}0.025^{*} \\
(0.014)\end{array}$ & $\begin{array}{c}0.019 \\
(0.017)\end{array}$ & $\begin{array}{c}0.018 \\
(0.017)\end{array}$ & $\begin{array}{c}0.027 \\
(0.018)\end{array}$ \\
\hline First-stage regression & & & & $\begin{array}{c}2.842 * * * \\
(0.595)\end{array}$ & $\begin{array}{c}3.131 * * * \\
(0.745)\end{array}$ & $\begin{array}{c}3.202 * * * \\
(0.812)\end{array}$ \\
\hline F-statistics & & & & 23.189 & 18.082 & 18.238 \\
\hline \multicolumn{7}{|c|}{ PANEL C - Data time period: 2014-17 } \\
\hline Adult Intensive Care Beds & $\begin{array}{l}-0.062 \\
(0.045)\end{array}$ & $\begin{array}{l}-0.104 * \\
(0.060)\end{array}$ & $\begin{array}{l}-0.104 * \\
(0.061)\end{array}$ & $\begin{array}{l}-0.048 \\
(0.056)\end{array}$ & $\begin{array}{c}-0.137 * * \\
(0.062)\end{array}$ & $\begin{array}{c}-0.132 * * \\
(0.062)\end{array}$ \\
\hline Neonatal Intensive Care Beds & $\begin{array}{c}0.02 \\
(0.034)\end{array}$ & $\begin{array}{c}0.015 \\
(0.035)\end{array}$ & $\begin{array}{c}0.024 \\
(0.034)\end{array}$ & $\begin{array}{c}0.016 \\
(0.048)\end{array}$ & $\begin{array}{l}-0.010 \\
(0.043)\end{array}$ & $\begin{array}{c}0.004 \\
(0.042)\end{array}$ \\
\hline First-stage regression & & & & $\begin{array}{c}3.914 * * * \\
(0.765)\end{array}$ & $\begin{array}{c}4.323 * * * \\
(0.926)\end{array}$ & $\begin{array}{c}4.309 * * * \\
(1.026)\end{array}$ \\
\hline F-statistics & & & & 26.607 & 22.278 & 20.700 \\
\hline \multicolumn{7}{|l|}{ Controls for } \\
\hline Year Fixed Effects & Yes & Yes & Yes & Yes & Yes & Yes \\
\hline Province Fixed Effects & Yes & Yes & Yes & Yes & Yes & Yes \\
\hline 5 Region Linear Time Trends & No & Yes & No & No & Yes & No \\
\hline 5 Region-Year Fixed Effects & No & No & Yes & No & No & Yes \\
\hline
\end{tabular}

Notes: Information on the health infrastructure variables is obtained from TurkStat. The full sample is for the 2009-17 period, excluding 2012, at the 81-province level. The number of observations is 648 in panel (A), whereas it is 324 in panel (B) and in panel (C) as the variables in these panels are available for recent years only. Each cell shows the estimates for the ratio of migrants to natives. The 2SLS regression instruments the key variable of interest using a distance-based cross-country instrument. The set of province-specific control variables included in the regressions are a set of geographical-area and year specific control variables as indicated above, the ratios of women with different levels of educational attainment (primary or secondary school, high school, and university or higher), the average household size, literacy rate, the fraction of women never-married, the average age of first-marriage for women, and the logarithm of GDP per capita. Regressions are weighted using province populations. Standard errors, given in parentheses, are clustered at the province level. *, **, or $* * *$ indicates significance at the $10 \%, 5 \%$ and $1 \%$ levels, respectively. 
Table A6: Effect of Refugees on Mortality Outcomes - without Logarithmic Transformation of the Dependent Variable

\begin{tabular}{|c|c|c|c|c|c|c|}
\hline \multicolumn{7}{|c|}{ Dependent Variable: Mortality Rate } \\
\hline \multirow[b]{2}{*}{ Age/Month/Day Period } & (1) & (2) & (3) & (4) & (5) & (6) \\
\hline & \multicolumn{3}{|c|}{ OLS } & \multicolumn{3}{|c|}{ 2SLS } \\
\hline Under Age 1 & $\begin{array}{c}0.935 \\
(2.382)\end{array}$ & $\begin{array}{c}1.736 \\
(2.556)\end{array}$ & $\begin{array}{c}4.116 \\
(2.831)\end{array}$ & $\begin{array}{l}-6.370 \\
(6.562)\end{array}$ & $\begin{array}{l}-6.849 \\
(5.826)\end{array}$ & $\begin{array}{l}-2.512 \\
(6.160)\end{array}$ \\
\hline Under Age 5 & $\begin{array}{c}0.207 \\
(0.137)\end{array}$ & $\begin{array}{c}0.150 \\
(0.152)\end{array}$ & $\begin{array}{l}0.321^{*} \\
(0.162)\end{array}$ & $\begin{array}{l}-1.603 \\
(5.848)\end{array}$ & $\begin{array}{l}-3.160 \\
(5.201)\end{array}$ & $\begin{array}{c}1.753 \\
(5.386)\end{array}$ \\
\hline Day 0 & $\begin{array}{c}-0.051 \\
(1.080)\end{array}$ & $\begin{array}{l}-0.126 \\
(1.033)\end{array}$ & $\begin{array}{c}0.282 \\
(1.085)\end{array}$ & $\begin{array}{l}-0.653 \\
(2.421)\end{array}$ & $\begin{array}{l}-1.231 \\
(2.605)\end{array}$ & $\begin{array}{l}-0.345 \\
(2.669)\end{array}$ \\
\hline Days 1-6 & $\begin{array}{c}0.915 \\
(1.419)\end{array}$ & $\begin{array}{c}0.932 \\
(1.552)\end{array}$ & $\begin{array}{c}1.514 \\
(1.725)\end{array}$ & $\begin{array}{l}-2.230 \\
(3.290)\end{array}$ & $\begin{array}{l}-2.887 \\
(2.704)\end{array}$ & $\begin{array}{l}-1.906 \\
(3.412)\end{array}$ \\
\hline Week 1 & $\begin{array}{c}0.864 \\
(2.114)\end{array}$ & $\begin{array}{c}0.806 \\
(2.086)\end{array}$ & $\begin{array}{c}1.796 \\
(2.365)\end{array}$ & $\begin{array}{l}-2.883 \\
(5.438)\end{array}$ & $\begin{array}{l}-4.118 \\
(4.959)\end{array}$ & $\begin{array}{l}-2.251 \\
(5.709)\end{array}$ \\
\hline Days 7-29 & $\begin{array}{c}0.203 \\
(0.678)\end{array}$ & $\begin{array}{c}0.714 \\
(0.730)\end{array}$ & $\begin{array}{l}1.554^{* *} \\
(0.660)\end{array}$ & $\begin{array}{l}-1.836 \\
(1.533)\end{array}$ & $\begin{array}{l}-1.378 \\
(1.453)\end{array}$ & $\begin{array}{l}-0.028 \\
(1.182)\end{array}$ \\
\hline Days 1-29 & $\begin{array}{c}1.118 \\
(1.813)\end{array}$ & $\begin{array}{c}1.645 \\
(2.038)\end{array}$ & $\begin{array}{c}3.067 \\
(2.241)\end{array}$ & $\begin{array}{l}-4.066 \\
(4.586)\end{array}$ & $\begin{array}{l}-4.265 \\
(3.913)\end{array}$ & $\begin{array}{l}-1.934 \\
(4.343)\end{array}$ \\
\hline Under Month 1 & $\begin{array}{c}1.067 \\
(2.539)\end{array}$ & $\begin{array}{c}1.520 \\
(2.609)\end{array}$ & $\begin{array}{c}3.350 \\
(2.872)\end{array}$ & $\begin{array}{l}-4.719 \\
(6.766)\end{array}$ & $\begin{array}{l}-5.496 \\
(6.182)\end{array}$ & $\begin{array}{l}-2.280 \\
(6.644)\end{array}$ \\
\hline Month 1-11 & $\begin{array}{c}-0.252 \\
(0.649)\end{array}$ & $\begin{array}{c}0.146 \\
(0.688) \\
\end{array}$ & $\begin{array}{c}0.759 \\
(0.770)\end{array}$ & $\begin{array}{c}-2.000 * * \\
(0.965) \\
\end{array}$ & $\begin{array}{l}-1.547 \\
(1.139)\end{array}$ & $\begin{array}{l}-0.329 \\
(1.106)\end{array}$ \\
\hline First-stage regression & & & & $\begin{array}{c}2.563 * * * \\
(0.491)\end{array}$ & $\begin{array}{c}2.850 * * * \\
(0.606)\end{array}$ & $\begin{array}{c}2.883 * * * \\
(0.666)\end{array}$ \\
\hline F-statistics & & & & 27.040 & 21.997 & 19.057 \\
\hline Ages: $65+$ & $\begin{array}{c}0.012 \\
(0.045)\end{array}$ & $\begin{array}{l}-0.020 \\
(0.042) \\
\end{array}$ & $\begin{array}{l}-0.031 \\
(0.041)\end{array}$ & $\begin{array}{c}4.419 \\
(3.368) \\
\end{array}$ & $\begin{array}{l}2.136 \\
(2.775)\end{array}$ & $\begin{array}{c}1.898 \\
(2.859)\end{array}$ \\
\hline First-stage regression & & & & $\begin{array}{c}2.662 * * * \\
(0.513)\end{array}$ & $\begin{array}{c}2.922 * * * \\
(0.671)\end{array}$ & $\begin{array}{c}2.940^{* * * *} \\
(0.730)\end{array}$ \\
\hline F-statistics & & & & 26.714 & 18.877 & 16.507 \\
\hline Ages: $75+$ & $\begin{array}{l}-0.031 \\
(0.116) \\
\end{array}$ & $\begin{array}{l}-0.079 \\
(0.097) \\
\end{array}$ & $\begin{array}{l}-0.090 \\
(0.097) \\
\end{array}$ & $\begin{array}{c}8.188 \\
(11.134) \\
\end{array}$ & $\begin{array}{c}3.295 \\
(11.799) \\
\end{array}$ & $\begin{array}{c}3.192 \\
(12.189) \\
\end{array}$ \\
\hline First-stage regression & & & & $\begin{array}{c}2.705^{* * *} \\
(0.554)\end{array}$ & $\begin{array}{c}2.976^{* * * *} \\
(0.724)\end{array}$ & $\begin{array}{c}2.999 * * * \\
(0.787)\end{array}$ \\
\hline F-statistics & & & & 23.694 & 16.827 & 14.748 \\
\hline All Ages & $\begin{array}{c}0.026 \\
(0.061) \\
\end{array}$ & $\begin{array}{l}-0.056 \\
(0.054) \\
\end{array}$ & $\begin{array}{l}-0.049 \\
(0.054) \\
\end{array}$ & $\begin{array}{l}-0.014 \\
(0.406) \\
\end{array}$ & $\begin{array}{c}-0.516 \\
(0.348) \\
\end{array}$ & $\begin{array}{c}-0.331 \\
(0.362) \\
\end{array}$ \\
\hline First-stage regression & & & & $\begin{array}{c}2.536^{* * *} \\
(0.445)\end{array}$ & $\begin{array}{c}2.795 * * * \\
(0.562)\end{array}$ & $\begin{array}{c}2.816^{* * *} \\
(0.617)\end{array}$ \\
\hline F-statistics & & & & 32.184 & 24.588 & 21.154 \\
\hline \multicolumn{7}{|l|}{ Controls for } \\
\hline Year Fixed Effects & Yes & Yes & Yes & Yes & Yes & Yes \\
\hline Province Fixed Effects & Yes & Yes & Yes & Yes & Yes & Yes \\
\hline 5 Region Linear Time Trends & No & Yes & No & No & Yes & No \\
\hline 5 Region-Year Fixed Effects & No & No & Yes & No & No & Yes \\
\hline
\end{tabular}

Notes: Data come from TurkStat. The sample includes 81 provinces in the 2009-2017 period excluding year 2012. The number of observations is 648 . Each cell comes from a separate regression and shows the estimates for the ratio of migrants to natives. The 2SLS regression instruments the key variable of interest using a distance-based cross-country instrument. The set of province-specific control variables included in the regressions are a set of geographical-area and year specific control variables as indicated above, the ratios of women with different levels of educational attainment (primary or secondary school, high school, and university or higher), the average household size, literacy rate, the fraction of women never-married, the average age of first-marriage for women, and the logarithm of GDP per capita. Regressions are weighted using the number of births by province in infant and child mortality regressions and using the populations of age groups by province in mortality regressions by age. Standard errors, given in parentheses, are clustered at the province level. *, ${ }^{* *}$, or $* * *$ indicates significance at the $10 \%, 5 \%$ and $1 \%$ levels, respectively. 
Figure A1: Number of Syrian Refugees in Turkey over Time

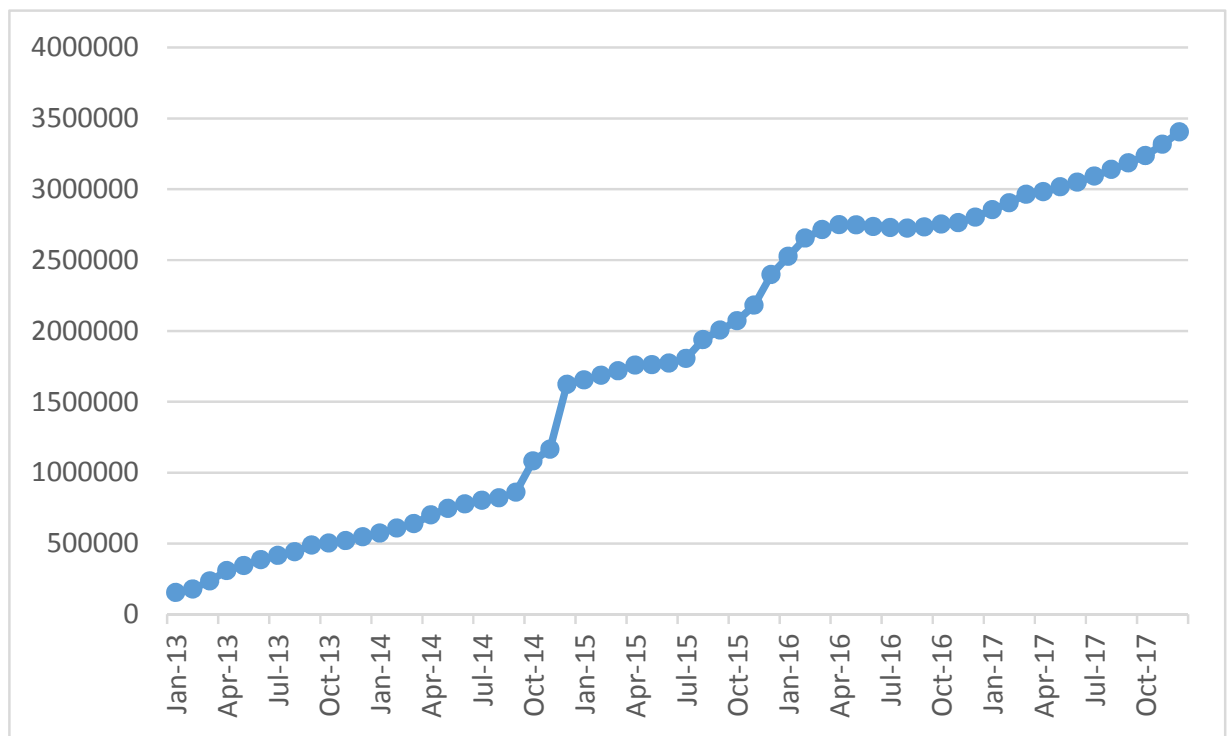

Source: UNHCR 